\title{
Use of residual materials for synthesis of lightweight granulates by thermal treatment process
}

\author{
N. Kanari, F. Diot, C. Gauthier and J. Yvon \\ Université de Lorraine, UMR 7359 CNRS, CREGU, GeoRessources Laboratory, 2 rue du Doyen \\ Roubault, TSA 70605, Vandoeuvre-lès-Nancy Cedex, F-54518, France.
}

\begin{abstract}
The general scope of this paper is to explore the formulation and the production, by thermochemical transformations, of expanded lightweight granulates incorporating residual materials as kaolinitic waste, sewage sludge, schist fines and wasted glass. The possible application fields are light concretes, road engineering, water treatment and hydroponic agriculture. The benefits can be multiple: creation of new resources from wastes; preservation of primary resources; humid zones on the river banks and the natural course of rivers; management of hazardous residual materials.

Tests on the thermal treatment and the thermochemical expansion were conducted in horizontal experimental set-up including a static electrical furnace. Raw material mixtures and treatment products were examined by visible microscopy, scanning electron microscopy-energy dispersive spectroscopy (SEM-EDS), X-ray diffraction (XRD) and infrared spectroscopy (IR) in order to understand the thermal behaviors of the chosen samples. Data analysis of the experimental results showed the possibility of obtaining the expanded granulates at temperatures lower than or equal to $1100^{\circ} \mathrm{C}$ for a firing time of a few minutes. The optimal temperature for their synthesis is a function of fluxes content and decreased significantly with increase of the wasted glass amount. Obtained granulates have a density lower than unity and they have good mechanical strength fulfilling the conditions for their use as building materials.

Sewage sludge, wasted glass as well as incinerator ashes can be used as alternative materials, among other industrial solid wastes, in the formulation of lightweight clay and schist based granulates. Results of this work try to meet the principles of sustainable mining and decreased pressure on the environment.
\end{abstract}

Keywords: Residual materials, kaolinitic waste 'KW', sewage sludge, lightweight granulates. 


\section{Introduction}

Using natural lightweight materials for the construction purpose is known since Roman times. Pumice and scoria, the oldest of these materials, are of volcanic origin and can be used after simple mechanical operations (Chandra and Berntsson, 2002). But, their occurrence is related to the eruption actions of volcanos, therefore their abundance has a heterogeneous geographical distribution. Nowadays, there is a great interest for the use of the natural materials and/or aggregates that undergo thermal expansion under controlled conditions. The perlite and some lamellar minerals i.e. vermiculite, clay, schist, shale, slate are the most identified raw materials used for the thermal synthesis of the lightweight aggregates. An excessive exploitation of these non-renewable natural resources will lead to their depletion in the future. In addition, the reserves in granulates of developed countries become lower and lower and their exploitation is severely regulated due to environmental constraint concerning the water flow management and the protection of humid zones. In this context, attempts were made to replace, at some extents, the natural materials by residual substances. However, these solid wastes and by-products have to accomplish the principles of the expansion process based upon two phenomena: (i) the formation of a continuous plastic phase, and (ii) the presence of volatile matter under certain pressure trapped inside this phase creating bubbles that generate the expansion. This plastic phase is formed when the materials are heated and transformed into a softened and/or partially liquid state. Depending on the physical properties of materials, the softening temperatures varied widely reaching, in some cases, more than $1500^{\circ} \mathrm{C}$. Most of the common chemical substances able to generate gases undergo this phenomenon at temperatures lower than $1000^{\circ} \mathrm{C}$. Note as examples: the combustion and/or pyrolysis of organic matter; the release of bonded/chemical water; the decomposition of sulphates, hydrated phosphates, carbonates; the oxidation of sulphides, etc. Hence, a large difference between the softening temperature and the gasification 
temperature mostly leads to sintering rather than expansion. This is due to gas leakage after that the continuous fluid phase is formed.

As could be expected, the elemental composition of materials undergoing thermal expansion are composed of the most abundant elements of the earth crust, i.e. $\mathrm{O}, \mathrm{Si}, \mathrm{Al}, \mathrm{Fe}, \mathrm{Ca}, \mathrm{Na}, \mathrm{K}, \mathrm{Mg}$ representing the rock-forming elements with $\mathrm{SiO}_{2}$ as the main constituent. Therefore, they are generated during mining, mineral processing and other pre-treatment process of raw materials, metallurgical extraction of valuable metals, chemical purification and metals refining as well as at the end-of-life products. Sterile residues, harbor sediments, tailings, slags, sludges, ashes, dusts, wasted glass are the most common and generic names of them. Addition and incorporation of two or more residual substances in the formulation of materials to be thermally expanded is often recommended allowing mixtures satisfying the necessary and sufficient conditions for the expansion as mentioned above. One may underline that it is important to decrease the soften temperature of the materials to be expanded. One possibility to achieve that in a given system is to add materials containing so called "fluxes". They are well known in extractive metallurgy during slag formation as well as in the glass industry. A typical example is illustrated in Fig. 1 representing the phase equilibrium diagram for Na-Si-O system (Levin et al., 1964). It contains three binary compounds: the orthosilicate $\left(2 \mathrm{Na}_{2} \mathrm{O} \cdot \mathrm{SiO}_{2}\right)$, the metasilicate $\left(\mathrm{Na}_{2} \mathrm{O} \cdot \mathrm{SiO}_{2}\right)$, and the disilicate $\left(\mathrm{Na}_{2} \mathrm{O} \cdot 2 \mathrm{SiO}_{2}\right)$. The two last compounds melt congruently at about $1090^{\circ} \mathrm{C}$ and $875^{\circ} \mathrm{C}$, respectively. However, the most important part of this diagram is to contain more than $70 \% \mathrm{SiO}_{2}$ corresponding to the composition of the most common glasses. An eutectic $\left(\mathrm{Na}_{2} \mathrm{O} \cdot \mathrm{SiO}_{2}-\mathrm{SiO}_{2}\right)$ occurs at about $74 \% \mathrm{SiO}_{2}$ and $793^{\circ} \mathrm{C}$ (Fig. 1) resulting in an important decrease of melting point of the mixture. For this raison, it is suggested to add wasted glass in the formulation of the lightweight materials. Phase diagrams of three $\left(\mathrm{Na}_{2} \mathrm{O}-\mathrm{Al}_{2} \mathrm{O}_{3}-\mathrm{SiO}_{2}\right)$ and other oxides are also available in the literature describing equilibrium phase composition and their evolution with temperature. 
As overviewed recently (Zhang, 2013; Monteiro and Vieira, 2014) extensive works were devoted to the incorporation of wastes in fired clay ceramics.

Many investigations were devoted to the use of various coproducts, residues and wastes for incorporating in the lightweight materials. In a recent work (Quina et al., 2014), the air pollution control residues from municipal solid waste incineration is used at low extent $(<10 \%)$ to substitute clay for the preparation of lightweight aggregates. A study of González-Corrochano et al. (2014) reports the synthesis of lightweight aggregates at $1150^{\circ} \mathrm{C}$ using mining and industrial waste as raw materials. The manufacture of the lightweight aggregates by incorporating fly ashes and reaction ashes with reservoir sediments at $1150-1200^{\circ} \mathrm{C}$ is investigated by Chen et al. (2010). Recycling of harbour sediment via lightweight materials is considered as an appropriate route thanks to its proper chemical composition and particle size distribution (Wei et al., 2008). The authors concluded that leaching levels of trace metals including $\mathrm{Pb}, \mathrm{Hg}, \mathrm{As}, \mathrm{Cd}, \mathrm{Cu}$, and $\mathrm{Cr}$ from all lightweight aggregate samples are less than regulatory limits. Stabilization of heavy metals in the lightweight materials is also demonstrated by Xu et al. (2013).

In this optic, the objective of this study is to investigate the synthesis of the lightweight granulates starting from only wastes and by-products such as kaolinitic waste, sewage sludge, schist fines, and wasted glass. As the first step of the investigation, much attention was paid to the thermal behaviour of these materials and to their mineralogical evolution as a function of the temperature between $150^{\circ} \mathrm{C}$ and $1200^{\circ} \mathrm{C}$. Thereafter, the binary and ternary prepared mixtures were subjected to the thermal expansion by firing between $1000^{\circ} \mathrm{C}$ and $1200^{\circ} \mathrm{C}$.

\section{Materials and methods}

Multiple samples coming from the industrial exploitation of kaolinitic and schist deposits, wastewater treatment plants as well as from end-of-life glass materials were collected for this investigation. They were used in powder form for the individual thermal treatment. General 
morphological aspects of the initial samples examined by SEM as well as their composition, expressed as simple oxides for main elements, are grouped in Fig. 2. The kaolinitic waste ' $\mathrm{KW}$ ' sample (Fig. 2a) has a broad particle size with a $\mathrm{d}_{90}$ equal to $183 \mu \mathrm{m}$ and it is used in bulk state without further grinding or sizing process. The sample has high contents of silica and alumina as well as the potassium oxide which will promote the decrease of the softening and/or melting point of the system. The sewage sludge 'SS' sample (Fig. 2b) possesses a complex composition which is linked to their process generation. Besides silica and alumina, this sample contains appreciable amounts of calcium, phosphorus, iron and magnesium compounds. Five major elements constituting the schist fines 'SF' sample (Fig. 2c) are silicon, aluminium, iron, potassium and magnesium. Finally, the composition of the wasted glass 'WG' sample (Fig. 2d) reflects its origin being a soda-lime-silica glass originating from the recycling of the glass containers.

The binary and ternary formulations at various proportions of the above mentioned materials were prepared and the composition of some typical mixtures (M1 through M4) is given in Table 1. To prepare the mixtures, definite proportions of KW, SS, SF and WG (Table 1) were thoroughly mixed and homogenized. Thereafter, the obtained products are blended with water to form a pasty material which is rolled by hand as granulates of centimetric size.

Raw materials and the prepared granulates were dried in an oven at $60^{\circ} \mathrm{C}$ for evaporating the free water before thermal treatment and different analysis tests. Thermal experimental trials were conducted in horizontal set-ups including a system of static tubular furnaces able to reach $1600^{\circ} \mathrm{C}$. For the thermal treatment tests, the sample is introduced directly into the furnace already preheated at desired temperature and when the dwell time is reached, the sample is removed from the furnace and cooled down to room temperature. Air was used as flow gas and it also assured the combustion of the organic matter contained in the mixtures. The outlet gases were cooled at room temperature leading to the condensation of the vapor phase and the recovery of a solid condensate mixed with the soot. Initial raw materials and solid products obtained from 


\begin{tabular}{|c|c|c|c|c|}
\hline Mixtures & Kaolinitic waste ' $\mathrm{KW}$ ' & Sewage sludge 'SS' & Schist fines 'SF' & Wasted glass 'WG' \\
\hline M1 & & 25 & 75 & \\
\hline M2 & & 20 & 60 & 20 \\
\hline M3 & 40 & 20 & & 40 \\
\hline M4 & 50 & 20 & & 30 \\
\hline
\end{tabular}

raw material mixtures and thermally expanded granulates were examined by visible microscopy, scanning electron microscopy-energy dispersive spectroscopy (SEM-EDS), X-ray diffraction (XRD), and infrared (DRIFTS) spectroscopy (IR). Solid condensates were subjected to SEMEDS analysis.

SEM examinations were performed by using a HITACHI S-4800 device equipped with an EDS elemental analysis microprobe. SEM imaging and chemical microanalysis were realized at accelerating voltage of $15 \mathrm{kV}$. The samples were carbon covered prior to analysis.

XRD was performed on powdered samples using a Bruker D8 Advance device, (Co Ka1 radiation, $\lambda=1.789 \AA$ ), under $35 \mathrm{kV}$ and $45 \mathrm{~mA}$ operating conditions. The acquisition of diffraction patterns was performed between $3^{\circ}$ and $64^{\circ}(2 \theta)$ range at step scan $0.034^{\circ}$ with $3 \mathrm{~s}$ per step. The XRD-patterns were analysed thanks to the DIFFRAC.EVA software and PDF-2 release 2011 database.

Diffuse reflectance infrared Fourier transform spectroscopy (DRIFTS) was performed using a Bruker IFS 55 spectrometer. The infrared spectra were collected between 600 and $4000 \mathrm{~cm}^{-1}$ wavenumber range with a $2 \mathrm{~cm}^{-1}$ resolution. Most infrared spectra were interpreted using previously reported data (Farmer, 1979). 


\section{Results and discussion}

155

156

157

158

159

160

161

162

163

164

\subsection{Isothermal treatment of initial samples}

The thermal treatment of the individual samples was carried out under isothermal conditions from $150^{\circ} \mathrm{C}$ to $1200^{\circ} \mathrm{C}$ for 30 minutes and the obtained data are plotted in Fig. 3. The evolution of the mass loss (ML\%) versus temperature during the treatment of the kaolinitic waste sample is drawn in Fig. 3a. The curve shape suggests that at least two phenomena can be distinguished at temperature lower and higher than $700^{\circ} \mathrm{C}$. By assuming that there is still kaolinite in the $\mathrm{KW}$ sample and after reviewing works related to the thermal behavior of the kaolinite clay, one may emphasis that the $\mathrm{ML} \%$ up to $700^{\circ} \mathrm{C}$ can be attributed to the dehydroxylation of kaolinite. Moreover, as the relative mass of water in pure kaolinite $\left[\mathrm{Al}_{2} \mathrm{Si}_{2} \mathrm{O}_{5}(\mathrm{OH})_{4}\right.$, i.e. $\left.\mathrm{Al}_{2} \mathrm{O}_{3} \cdot 2 \mathrm{SiO}_{2} \cdot 2 \mathrm{H}_{2} \mathrm{O}\right]$ is $13.96 \%$, one may suggest that the kaolinite content in the KW sample is around $10 \%$. Volatilization of the micas structural water contained in $\mathrm{KW}$ can be responsible for the $\mathrm{ML}$ observed at higher temperature. Nevertheless, the ML\% curve is an apparent reflection of the sample thermal behavior due to the broad size fractions of the KW sample used for the experimental tests and to the intrinsic transformation kinetics.

Data compilation for the sewage sludge treatment between $150^{\circ} \mathrm{C}$ and $1150^{\circ} \mathrm{C}$ is drawn in Fig. 3b. As could be expected, such materials are very complex in composition including organic matter, clays, carbonates, phosphates, sulphates, quartz, etc. Further, SS sample is constituted of intrinsic fine particles (several $\mu \mathrm{m}$ ) leading to an increased activity compared with $\mathrm{KW}$ sample. However, the ML curve shape for the SS treatment reflects two significant steps of ML\%. One may speculate that dehydration, combustion/decomposition of organic matter and clays dehydroxylation are produced at temperatures lower than $550^{\circ} \mathrm{C}$. Whilst the metal carbonate decomposition (most probably $\mathrm{CaCO}_{3}$ ) occurs at temperatures higher than $700^{\circ} \mathrm{C}$. Note that the final $\mathrm{ML} \%$ of the sample at $1100^{\circ} \mathrm{C}$ is more than 9 times higher than that of $\mathrm{KW}$ sample. 
The shape of the thermal treatment curve of the schist fines sample plotted in Fig. $3 \mathrm{c}$ indicated a continuous mass loss up to about $800^{\circ} \mathrm{C}$ with a value close to $4.5 \% \mathrm{ML}$. As expected, the ML of the wasted glass sample (Fig. 3c) is low with an average value of about $0.4 \%$ in the whole temperature range studied. These preliminary assumptions for the thermal behaviors of these samples are developed and discussed during interpretation of some XRD, IR and SEM-EDS results which are exposed below.

\subsection{Characterization of the thermal treatment products}

\subsubsection{Kaolinitic waste}

The results of the XRD measurements of the initial kaolinitic sample and the obtained residues at different treatment temperatures (from $300^{\circ} \mathrm{C}$ to $1200^{\circ} \mathrm{C}$ ) are displayed in Fig. 4 . Whilst, the IR (DRIFTS) results are summarized in Fig. 5. XRD analysis shows the presence of micas $\left\{\mathrm{Al}_{2}\left[\mathrm{AlSi}_{3} \mathrm{O}_{10}(\mathrm{OH}, \mathrm{F})_{2} \mathrm{~K}\right]\right.$-muscovite; $\left.\mathrm{Al}_{(2-\mathrm{x})}(\mathrm{Mg}, \mathrm{Fe})_{\mathrm{x}} \mathrm{Si}_{3} \mathrm{Al}\right)\left(\mathrm{K}, \mathrm{H}_{3} \mathrm{O}\right)_{\mathrm{x}}\left(\mathrm{O}_{10}\left[(\mathrm{OH})_{2},\left(\mathrm{H}_{2} \mathrm{O}\right)\right]\right.$-illite $\}$ as well as kaolinite $\left[\mathrm{Al}_{2} \mathrm{Si}_{2} \mathrm{O}_{5}(\mathrm{OH})_{4}\right]$ as major crystallized phases in the KW raw sample (Fig. 4a). Other major phases revealed by XRD consisted of quartz $\left(\alpha-\mathrm{SiO}_{2}\right)$, alkali feldspar $\left(\mathrm{KAlSi}_{3} \mathrm{O}_{8}\right)$ and schorl $\left[\mathrm{NaFe}^{2+}{ }_{3} \mathrm{Al}_{6}\left(\mathrm{BO}_{3}\right)_{3} \mathrm{Si}_{6} \mathrm{O}_{18}(\mathrm{OH})_{4}\right]$, note that this mineral contains borate ions and acts as a flux. SEM-EDS analysis of the non-treated kaolinitic waste confirms the occurrence of the above mentioned phases in selected sample particles. Titanium, tin, tantalum, niobium and iron oxides were also revealed by SEM-EDS analysis. It should be noted that their phase content is low to be detected by usual XRD analysis. The thermal treatment of the KW resulted into the decrease of the peaks intensity of kaolinite with an increase of the temperature; in addition, typical peaks of kaolinite disappeared for the temperature higher than $600^{\circ} \mathrm{C}$. Higher temperatures (approaching $1000^{\circ} \mathrm{C}$ ) are required for breakage-down of muscovite/illite (micas) structure (Fig. 4b). The characteristic peaks of the schorl phase are no more detected beyond $900^{\circ} \mathrm{C}$. Note that schorl appeared as a minor phase even in the initial KW sample. Products obtained at temperatures exceeding $900^{\circ} \mathrm{C}$ are mostly composed of feldspar and quartz. 
As shown by Fig. 5, the IR spectrum of KW raw sample exhibits the bands near the three characteristic bands at 3696,3652 and $3620 \mathrm{~cm}^{-1}$ that can be attributed to [Al-O-H] stretching of disordered kaolinite. More precisely, the last band is characteristic of inner hydroxyls, while the two first ones are assigned to vibrations of external hydroxyls. The bands close to $3620 \mathrm{~cm}^{-1}$ could also be assigned to the hydroxyl vibrations in the muscovite and illite and they overlap due to the similarities of Al-OH bond of these two minerals.

As presented in Fig. 5, the IR spectra of the KW treated at various temperatures can be classified in three groups depending on the temperature: (i) from $300^{\circ} \mathrm{C}$ to $600^{\circ} \mathrm{C}$; (ii) between $700^{\circ} \mathrm{C}$ and $900^{\circ} \mathrm{C}$ and (iii) $1000^{\circ} \mathrm{C}-1200^{\circ} \mathrm{C}$. By combining the results of ML versus temperature (Fig. 3a) with XRD (Fig. 4) and IR and results, one may conclude that quasi-full dehydroxylation of kaolinite contained in the $\mathrm{KW}$ is achieved at about $600^{\circ} \mathrm{C}$ for 30 minutes. Similar findings were reported early (Gasparini et al., 2013).

\subsubsection{Sewage sludge}

Results of the above mentioned analysis upon the initial sewage sludge sample confirms the multiphase nature of this material. Figs. 6 and 7 represent, respectively, the XRD and IR analysis results of the products generated during heating of the sewage sludge. The mineral composition of the initial SS sample represents a mixture of micas, kaolinite, feldspar, anhydrite $\left(\mathrm{CaSO}_{4}\right)$, quartz and calcite. Besides the characteristic bands ascribed to kaolinite, muscovite/illite, carbonate and quartz prevailed in the raw sample, the IR measurement confirms the presence of the organic matter (Fig. 7a).

Gathering the data displayed in Figs 3b, 6 and 7 allowed the explication of the SS thermal behaviors. The thermal treatment under $300^{\circ} \mathrm{C}$ led to destabilization/destruction of organic matter as indicated by the absence of the absorbance bands at $2820-2959 \mathrm{~cm}^{-1}$ attributed to diverse C-H stretching (Fig. 7). The dehydroxylation of the silico-aluminates is shifted towards 
low temperatures compared with kaolinitic waste. This is probably due to the fine particle size of sewage sludge as well as the exothermic nature of the reaction of organic matter with oxygen. The plateau of the mass loss observed during treatment of the sample at around $550^{\circ} \mathrm{C}$ (Fig. $3 \mathrm{~b}$ ) confirms an almost full reaction of hydrocarbons with oxygen and a complete removal of the structural kaolinite water at temperatures lower than or equal to $500^{\circ} \mathrm{C}$.

Decomposition of carbonates $\left(\mathrm{CaCO}_{3}\right.$ according to $\mathrm{XRD}$, Fig. $\left.6 \mathrm{~b}\right)$ generating carbon dioxide is the major occurred transformation. The doublet band at $2340-2349 \mathrm{~cm}^{-1}$ (Fig. $7 \mathrm{~b}$ ) is assigned to gaseous $\mathrm{CO}_{2}$. One may speculate that the evolved $\mathrm{CO}_{2}$ is trapped in the soften glass creating closed micropores. This hypothesis is confirmed by the fact that the product obtained at $1150^{\circ} \mathrm{C}$ is free of $\mathrm{CO}_{2}$ as it is fully melted leading to the carbon dioxide escape. Further, the remove of the $\mathrm{CO}_{2}$, involved and trapped in the porous SS product at medium temperature, may provoke the $\mathrm{ML} \%$ observed at temperatures higher than $950^{\circ} \mathrm{C}$.

These deduced observations show that the decomposition of carbonates guarantees one of the necessary conditions for the thermal expansion of the materials. While, the presence of phosphorous and potassium compounds (confirmed by SEM-EDS results) resulting in the apparition of the liquid phase at relatively low temperatures which may be converted into amorphous glass during cooling. The XRD patterns at high temperatures (Fig. 6b) showed neoformed phases difficult to be identified (e.g. $\mathrm{d}=5.18 \AA$ ) and some other ones belonging probably to pyroxene group. However, the quartz, anhydrite and feldspar remain the major crystallized phases of the sewage sludge sample treated at temperatures higher than $800^{\circ} \mathrm{C}$.

\subsubsection{Schist fines}

A schist fines sample was also subjected to thermal treatment under air atmosphere up to $1200^{\circ} \mathrm{C}$. As in the previous cases, the elemental and mineralogical evolution as a function of the temperature was followed by above-mentioned analysis methods. Many of the obtained results 
are summarized in Figs. 8 and 9. According to the XRD patterns traced in Fig. 8a, the crystalline phases of the raw SF sample are chlorite, muscovite/illite (micas), kaolinite as well as feldspar and quartz. As indicated in Fig. 9a, the exhibited bands around 3559 and $3417 \mathrm{~cm}^{-1}$ can be attributed to $(\mathrm{AlFe}) \mathrm{O}-\mathrm{OH}$ and $(\mathrm{MgAl}) \mathrm{O}-\mathrm{OH}$ stretching, respectively, of fired kaolinite and chlorite with a general formula $\left[\mathrm{Mg}_{(6-\mathrm{x}-\mathrm{y})} \mathrm{Al}_{\mathrm{x}} \mathrm{Fe}_{\mathrm{y}} \mathrm{Si}_{(4-\mathrm{x})} \mathrm{Al}_{\mathrm{x}} \mathrm{O}_{10}(\mathrm{OH})_{8}\right]$. Further, the absorption spectra of the $\mathrm{OH}$ region presented the overlapping of an absorption band at around $3622 \mathrm{~cm}^{-1}$ by muscovite and illite.

Heating the SF sample leads to the dehydroxylation of kaolinite at $\mathrm{T}<650^{\circ} \mathrm{C}$. The structure of the hydroxide sheet of the present chlorite seems to be stable up to $775^{\circ} \mathrm{C}$ where the total volatilisation of its structural is achieved. Peak intensity of the muscovite/illite phase decreased with temperature and the peak signal of these compounds is absent in the diffractogram obtained at $\mathrm{T}>950^{\circ} \mathrm{C}$. Further heating (especially at $1200^{\circ} \mathrm{C}$ ) provokes the formation of partial liquid phase converted into glass during sample quenching in air. Besides quartz, the characteristic peaks of the spinel-like structure of the neo-formed hercynite $\left(\mathrm{FeAl}_{2} \mathrm{O}_{4}\right)$ were revealed by XRD in the schist product heated at $1200^{\circ} \mathrm{C}$.

\subsubsection{Wasted glass}

As already shown in Fig. 3c, the powdered wasted glass sample is heated at different temperatures for 30 minutes. Reminder that the sample was brought directly in the heated zone of the furnace and after reaching the fixed dwelling time, the sample is cooled in air to room temperature.

It was quite interesting to follow the mineralogical and morphological evolution of the WG thermal treatment products at various temperatures. The XRD patterns are grouped in Fig. 10. The initial WG diffractogram exhibits a broad diffraction band near to $27^{\circ}(2 \theta)$ indicating the XRD amorphous nature of the waste glass sample. The well-defined reflection at $3.24 \AA$ 
probably corresponds to a crystallized organic material since it disappears at low temperature. As shown by Fig. 10, the crystallization of WG started from temperatures higher than $600^{\circ} \mathrm{C}$. This phenomenon, known as glass devitrification, occurs beyond the glass transition temperature which oscillates between $520^{\circ} \mathrm{C}$ and $600^{\circ} \mathrm{C}$ for the classical soda-lime-silica glasses. The first phase to be crystallized seems to be the quartz which remains predominant phase up to $900^{\circ} \mathrm{C}$. Typical peaks of plagioclase (series of solid solution between albite- $\mathrm{NaAlSi}_{3} \mathrm{O}_{8}$ and anorthite$\mathrm{CaAl}_{2} \mathrm{Si}_{2} \mathrm{O}_{8}$ end-members $)$ and wollastonite $\left(\mathrm{CaSiO}_{3}\right)$ appeared in the diffractograms of samples heated at temperature higher than $800^{\circ} \mathrm{C}$. These components become the main crystallized phases at $1000^{\circ} \mathrm{C}$ which is evaluated to be lesser than the liquidus temperature of the used sodalime-silica glass, while the main phase of the WG treated at $1050^{\circ} \mathrm{C}$ is quartz. Further heating, at $1100^{\circ} \mathrm{C}$, led to a product slightly crystallised with low intensity peaks of quartz.

Several WG thermal treatment samples were subjected to SEM/EDS examination. The cross sections of the fired samples at $850^{\circ} \mathrm{C}$ and $950^{\circ} \mathrm{C}$ are given in Fig. 11. A bright star-like shaped phase into the glassy matrix appeared in the SEM micrograph of the sample obtained at $850^{\circ} \mathrm{C}$ (Fig. 11a). The morphology of the neo-formed crystalline phase is affected by the temperature and as shown in Fig. $11 \mathrm{~b}$, the needle-like crystals are abundant for the $\mathrm{WG}$ treated at $950^{\circ} \mathrm{C}$. The higher magnification of the SEM images gathered with the EDS results for both the samples are displayed in Fig. 12. The oxides contents of two kinds of crystals seem to roughly confirm the chemical composition of wollastonite. Other results acquired by SEM-EDS analysis indicate the presence of neo-formed and well-developed particles having the typical composition of plagioclase (Fig. 13a) and quartz (Fig. 13b).

Similar findings have been described in the literature during glass devitrification and glassceramic synthesis. Teixeira et al. (2014) reported the wollastonite formation during the production of the glass-ceramic material at temperatures lower than $900^{\circ} \mathrm{C}$. Another investigation (Yoon et al., 2013) revealed that the most appropriate temperature to produce 
wollastonite glass-ceramics containing acicular type crystalline phase with good mechanical property was between $1000^{\circ} \mathrm{C}$ and $1050^{\circ} \mathrm{C}$.

One may note that the nature, the amount and the shape of the crystalline phases are related especially to the composition of starting materials, crystallization temperature and time, heating and cooling rates as well as the presence of nucleation agents.

\subsection{Thermal expansion of granulates}

The above mentioned results gave general information about the elemental and mineralogical transformation occurring during the thermal treatment of the selected waste samples. They permit to establish an experimental procedure for the production of lightweight granulates starting by these waste materials. Various mixtures based on the binary and ternary formulations were tested for thermal expansion purpose. Some preliminary results of the work performed are described previously (Kanari et al., 2010). A comparison view of green granulates and those thermally treated under different conditions for the previously formulated mixtures (Table 1) is shown in Fig. 14. The bloating temperatures ranged from $1050^{\circ} \mathrm{C}$ and $1100^{\circ} \mathrm{C}$ for the firing times at 10 and 15 minutes. A substantial difference between green and expanded granulates is obvious whichever mixture is used for the thermal expansion. Further, the cross-section of the expanded granulates shows mostly two distinct zones i.e. the shell and the core of granulates. Their macro-morphology roughly demonstrates the principle of the thermal expansion mechanism linked to the formation of a sealed coat (the dense outside layer) trapping gases leading to the pore formation (gas-filled porous inner zone) during firing.

A typical microstructure of the obtained lightweight granulates is given in Fig. 15a. Various size pores (black zones) of rounded shape are obvious from the image. They are mostly enveloped by a vitreous matrix composed of $\mathrm{Si}, \mathrm{Ca}, \mathrm{Al}, \mathrm{K}, \mathrm{Na}$ oxides. However, the EDS spectra revealed the presence of some heavy metal bearing compounds in the expanded granulates. For instance, the 
bright spots of Fig. 15a are typically composed of copper and iron sulfides (Fig. 15b) originating

from the sewage sludge. Other heavy metals $(\mathrm{Cr}, \mathrm{Zn})$ are stabilized in the spinel phase of the expanded granulates (Kanari et al., 2010). Nevertheless, the SEM-EDS analysis of the obtained condensates showed the presence of $\mathrm{Zn}$ and $\mathrm{Pb}$ compounds indicating their partial volatilization during bloating process.

The aforementioned expanded mixtures were examined by XRD analysis and the obtained diffractograms displayed in Fig. 16 are of particular interest. Besides quartz, feldspar and anhydrite, they show the presence of the wollastonite phase in all expanded mixtures containing wasted glass (M2, M3, M4) although the expansion temperature is between $1050^{\circ} \mathrm{C}$ and $1100^{\circ} \mathrm{C}$. Reminder that during the thermal treatment of wasted glass alone (section 3.2.4), the wollastonite was not detected at temperatures higher than $1000^{\circ} \mathrm{C}$. One may speculate that in the case of the granulate expansion, the wollastonite nucleation is promoted by the presence of inert phases, such as $\mathrm{TiO}_{2}$, known as nucleating agent during glass-ceramic synthesis. Note that the titanium oxide is present in the starting materials (KW, SS and SF). Examination of the lightweight granulates (M3 expanded at $1050^{\circ} \mathrm{C}$ ) by SEM-EDS indicated the growth of whiskers-like shape (Fig. 17a) with a rough chemical composition (Fig. 17b) corresponding to wollastonite embedded in a glassy matrix (Fig. 17c). It should be noted that the presence of such compounds will improve the flexural strength of the expanded granulates.

The decrease of the expansion temperature is a function of the wasted glass amount in the granulate formulation. The soda-lime-silica glass acts as a flux for the granulates by lowering their softening temperature (see Fig. 1). As shown before, experimental tests using mixture designed as M3 (40\% KW $+20 \% \mathrm{SS}+40 \% \mathrm{WG})$ showed a good thermal expansion of the formulated granulates at $1050^{\circ} \mathrm{C}$, which is $50^{\circ} \mathrm{C}$ lower than that employed for the expansion of M4 (50\% KW $+20 \% \mathrm{SS}+30 \% \mathrm{WG})$. Preliminary examination of several physical properties of the obtained lightweight granulates showed that expanded M3 product had an apparent density of $0.69 \mathrm{~g} / \mathrm{cm}^{3}$ and it is characterized by the water absorption coefficient of $14.8 \%$. The granulates 
355 obtained during thermal expansion of $\mathrm{M} 1$ at $1100^{\circ} \mathrm{C}$ have a real density close to unity and a 356 compressive strength of 4.9 MPa which is comparable with those obtained for natural granulates 357 based on schist, allowing their use as building materials. More detailed data related to the 358 obtained lightweight granulates will be developed in the forthcoming studies.

\section{Conclusions}

Thermal treatments of individual wasted materials as well as the thermal expansion of theirs mixtures allow the following conclusions:

1. The main phases of the kaolinitic waste are: micas, feldspar, kaolinite, schorl and quartz. Thermal treatment of the samples showed the dehydration/decomposition of the kaolin at temperatures lower than $650^{\circ} \mathrm{C}$, whilst, the muscovite and other sheet silicates are broken down at around $1000^{\circ} \mathrm{C}$ resulting in quartz and refractory feldspar as well crystallized phases at $1200^{\circ} \mathrm{C}$.

2. At least two steps are observed during thermal treatment of the sewage sludge in air. The decomposition and/or combustion of the organic matter as well as the clay dehydroxylation occurred at temperatures lower than $650^{\circ} \mathrm{C}$. The calcite decomposition into $\mathrm{CaO}$ proceeds at higher temperatures involving carbon dioxide.

3. Complete dehydroxylation of the chlorite contained in the schist sample is achieved at temperatures lower than or equal to $775^{\circ} \mathrm{C}$. The thermal behaviors of other schist phases (kaolinite, muscovite, illite, feldspar) are similar to those observed for the kaolinitic waste.

4. The thermal treatment of the wasted glass led to the partial glass devitrification at temperatures higher than $700^{\circ} \mathrm{C}$. Quartz, plagioclase and wollastonite are identified as the main neo-formed crystalline phases. The wollastonite needle-like structure is 
considered as a suitable candidate for improving the strength of the fired product.

5. Results of the thermal expansion showed the possibility to manufacture the lightweight granulates at temperatures between $1050^{\circ} \mathrm{C}$ and $1100^{\circ} \mathrm{C}$ by using only residual materials. It may be stated that the optimal expansion temperature depends on the glass and sewage sludge contents of the prepared mixtures.

6. The resulting granulates are lightweight and they have a good mechanical strength meeting the conditions for their use as building materials. Other application fields are road engineering, water treatment and hydroponic agriculture.

This study investigates the possibility of using a wide spectrum of secondary raw materials for synthesizing lightweight granulates by thermochemical transformation. Results so far indicate the potential to achieve sustainable mining and processing as well as resource efficiency principles of maximizing yields.

\section{Acknowledgements}

The present work was performed in the frame of the European Union contract $\left(\mathrm{n}^{\circ} 310645\right)$ 'Sustainable Technologies for Calcined Industrial Minerals' (STOICISM), part of the European seventh framework programme for research (FP7). Another part was supported by the French National Research Agency 'ANR' Project-EXPANTHERM, through contract $\mathrm{n}^{\circ}$ ANR-06ECOT-010. A last part was supported by Bourgogne innovation 'Prestation Technologique de Réseau: Préparation par voie thermique de matériaux expansés légers destinés aux murs végétalisés', n PTRCRB1111-059. The authors thank these institutions for financial supports.

\section{References}

Chandra, S., Berntsson, L., 2002. Lightweight Aggregate Concrete, Noyes Publications, New York, USA. 
Chen, H.J., Wang, S.H., Tang, C.W., 2010. Reuse of incineration fly ashes and reaction ashes for manufacturing lightweight aggregate. Construct. Build. Mater. 24, 46-55.

Farmer, V.C., 1979. Infrared spectroscopy, in: van Olphen, H., Fripiat, J.J. (Eds.), Data Handbook for Clay Materials and other Non-metallic Minerals. Pergamon Press, Oxford, 285-337.

Gasparini, E., Tarantino, S. C., Ghigna, P., Riccardi, M.,P., Cedillo-González, E. I., Siligardi, C., Zema, M., 2013. Thermal dehydroxylation of kaolinite under isothermal conditions. Appl. Clay Sci. 80-81, 417-425.

González-Corrochano, B., Alonso-Azcárate, J., Rodas, M., 2014. Effect of prefiring and firing dwell times on the properties of artificial lightweight aggregates. Construct. Build. Mater. $52,91-101$.

Kanari, N., Banse, J., Joussemet, R., Diot, F., Allain, E., Yvon, J., Faure, F.X., Sevèque, J.L., Chambard, J.P., 2010. Synthesis of thermal expanded lightweight granulates incorporating wastes as raw materials. Proceedings of the XVIII ${ }^{\text {th }}$ International scientific and professionnal meeting "Ecological Truth” EcoIst'10. 1-4 June 2010, Apatin, Serbia, Edited by Zoran S. Markovic, pp. 458-465.

Levin, E.M., Robbins, C.R., McMurdie, H.F., 1964. Phase Diagrams for Ceramists, Vol. 1, American Ceramic Society, Columbus, OH, p. 94.

Monteiro, S.N., Vieira, C.M.F., 2014. On the production of fired clay bricks from waste materials: A critical update. Constr. Build. Mater. 68, 599-610.

Quina, M.J., Almeida, M.A., Santos, R., Bordado, J.M., Quinta-Ferreira, R.M., 2014. Compatibility analysis of municipal solid waste incineration residues and clay for producing lightweight aggregates. Appl. Clay Sci. 102, 71-80.

Teixeira, S.R., Magalhães, R.S., Arenales, A., Souza, A.E., Romero, M., Rincón, J.M., 2014. Valorization of sugarcane bagasse ash: Producing glass-ceramic materials. J. Environ. Manage. 134, 15-19. 
430 Wei, Y-L, Yang, J-C, Lin, Y-Y, Chuang, S-Y, Wang, H.P., 2008. Recycling of harbor sediment 431 as lightweight aggregate. Mar. Pollut. Bull. 57, 867-872.

432 Xu, G., Liu, M., Li, G, 2013. Stabilization of heavy metals in lightweight aggregate made from 433 sewage sludge and river sediment. J. Hazard. Mater. 260, 74-81.

434 Yoon, S.D., Lee, J.U., Lee, J.H., Yun, Y.H., Yoon, W.J., 2013. Characterization of wollastonite 435 glass-ceramics made from waste glass and coal fly ash. J. Mater. Sci. Technol. 29(2) 149436 153.

437 Zhang, L., 2013. Production of bricks from waste materials - a review. Constr. Build. Mater. 47, 438 643-655. 


\section{FIGURE CAPTIONS}

Fig. 1 : Phase diagram for $\mathrm{Na}_{2} \mathrm{O}-\mathrm{SiO}_{2}$ system, adapted from Levin et al. (1964).

Fig. 2 : Fig. 2. Morphological aspects of the initial samples and their oxide contents for: (a) kaolinitic waste; (b) sewage sludge; (c) schist fines; (d) wasted glass.

Fig. 3 : Evolution of sample mass loss as a function of temperature for: (a) kaolinitic waste; (b) sewage sludge; (c) schist fines and wasted glass during their isothermal treatment at 30 minutes.

Fig. 4 : XRD diagrams of the solid products issued from the thermal treatment of the kaolinitic waste sample up to $600^{\circ} \mathrm{C}(a)$ and from $700^{\circ} \mathrm{C}$ to $1200^{\circ} \mathrm{C}(b)$.

Fig. 5 : IR spectra (DRIFTS) of the solid products issued from the thermal treatment of the kaolinitic waste sample at different temperatures.

Fig. 6 : XRD diagrams of the solid products issued from the thermal treatment of the sewage sludge sample up to $650^{\circ} \mathrm{C}(a)$ and from $750^{\circ} \mathrm{C}$ to $1150^{\circ} \mathrm{C}(b)$.

Fig. 7 : IR spectra (DRIFTS) of the solid products issued from the thermal treatment of the sewage sludge sample up to $550^{\circ} \mathrm{C}(a)$ and from $650^{\circ} \mathrm{C}$ to $1150^{\circ} \mathrm{C}(b)$.

Fig. 8 : XRD diffractograms of the solid products issued from the thermal treatment of the schist sample between $200^{\circ} \mathrm{C}$ and $650^{\circ} \mathrm{C}(a)$ and from $750^{\circ} \mathrm{C}$ to $1200^{\circ} \mathrm{C}(b)$.

Fig. 9 : IR spectra (DRIFTS) of the solid products issued from the thermal treatment of the schist sample up to $650^{\circ} \mathrm{C}(a)$ and from $750^{\circ} \mathrm{C}$ to $1200^{\circ} \mathrm{C}(b)$.

Fig. 10 : XRD diffractograms of the solid products issued from the thermal treatment of the wasted glass sample between $400^{\circ} \mathrm{C}$ and $1100^{\circ} \mathrm{C}$.

Fig. 11 : Cross section of the wasted glass sample heated at $850^{\circ} \mathrm{C}(a)$ and $950^{\circ} \mathrm{C}(b)$.

Fig. 12 : SEM-EDS results of the wollastonite like crystals obtained during thermal treatment of the wasted glass sample at $850^{\circ} \mathrm{C}(a)$ and $950^{\circ} \mathrm{C}(b)$.

Fig. 13 : SEM-EDS results of plagioclase $(a)$ and quartz (b) particles obtained during thermal treatment of the wasted glass sample at $850^{\circ} \mathrm{C}$.

Fig. 14 : Photographs of green and expanded granulates for M1 (a), M2 (b), M3 (c) and M4 (d).

Fig. 15 : SEM image of the expanded $\mathrm{M} 3$ at $1050^{\circ} \mathrm{C}(a)$ and elemental composition of bright spots $(b)$.

Fig. 16 : XRD diffractograms of the thermally expanded granulates.

Fig. 17 : SEM-EDS results of the M3 expanded at $1050^{\circ} \mathrm{C}$ displaying: (a) morphologic aspects; (b) elemental composition of the 'whiskers'; $(c)$ elemental composition of the matrix. 


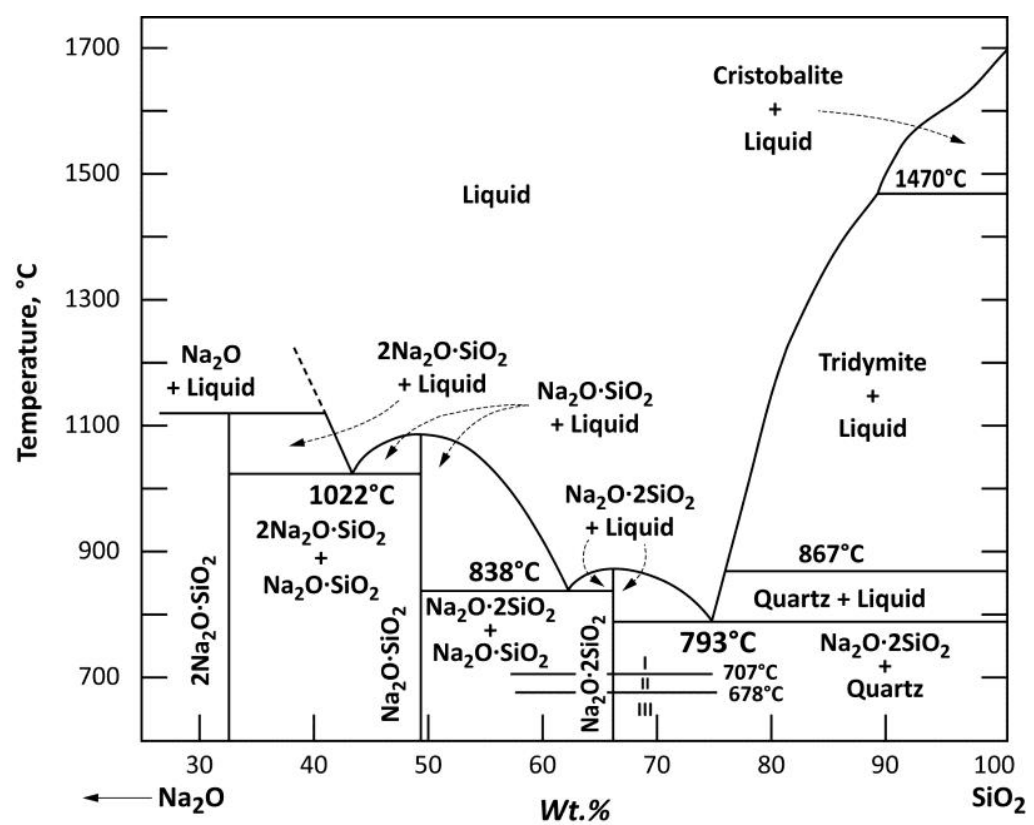



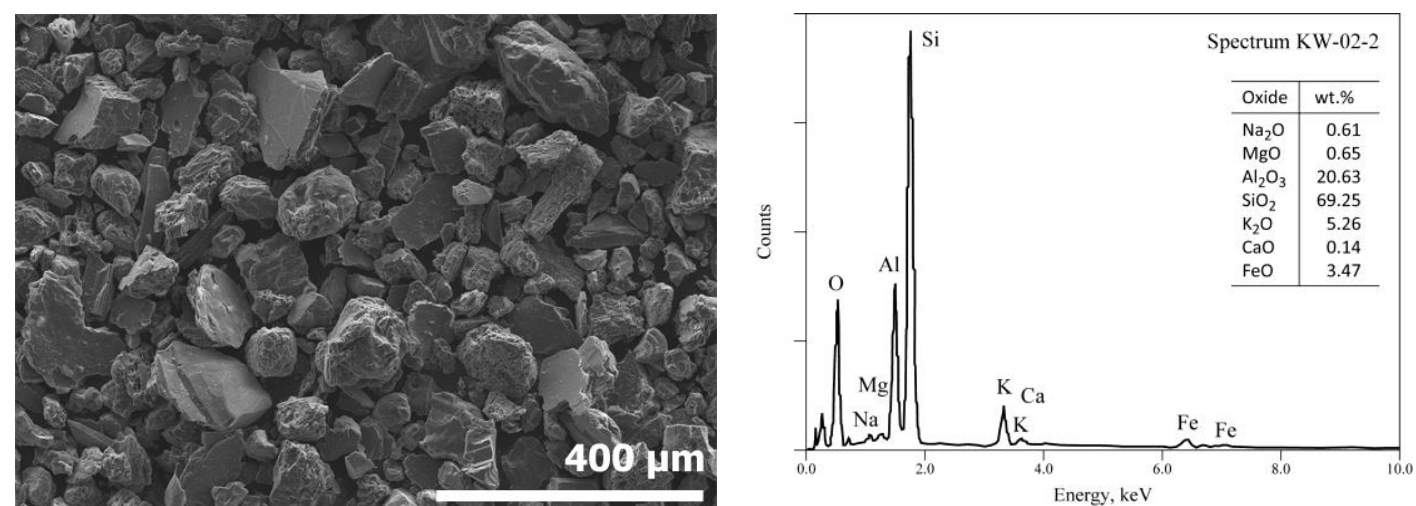

(a)
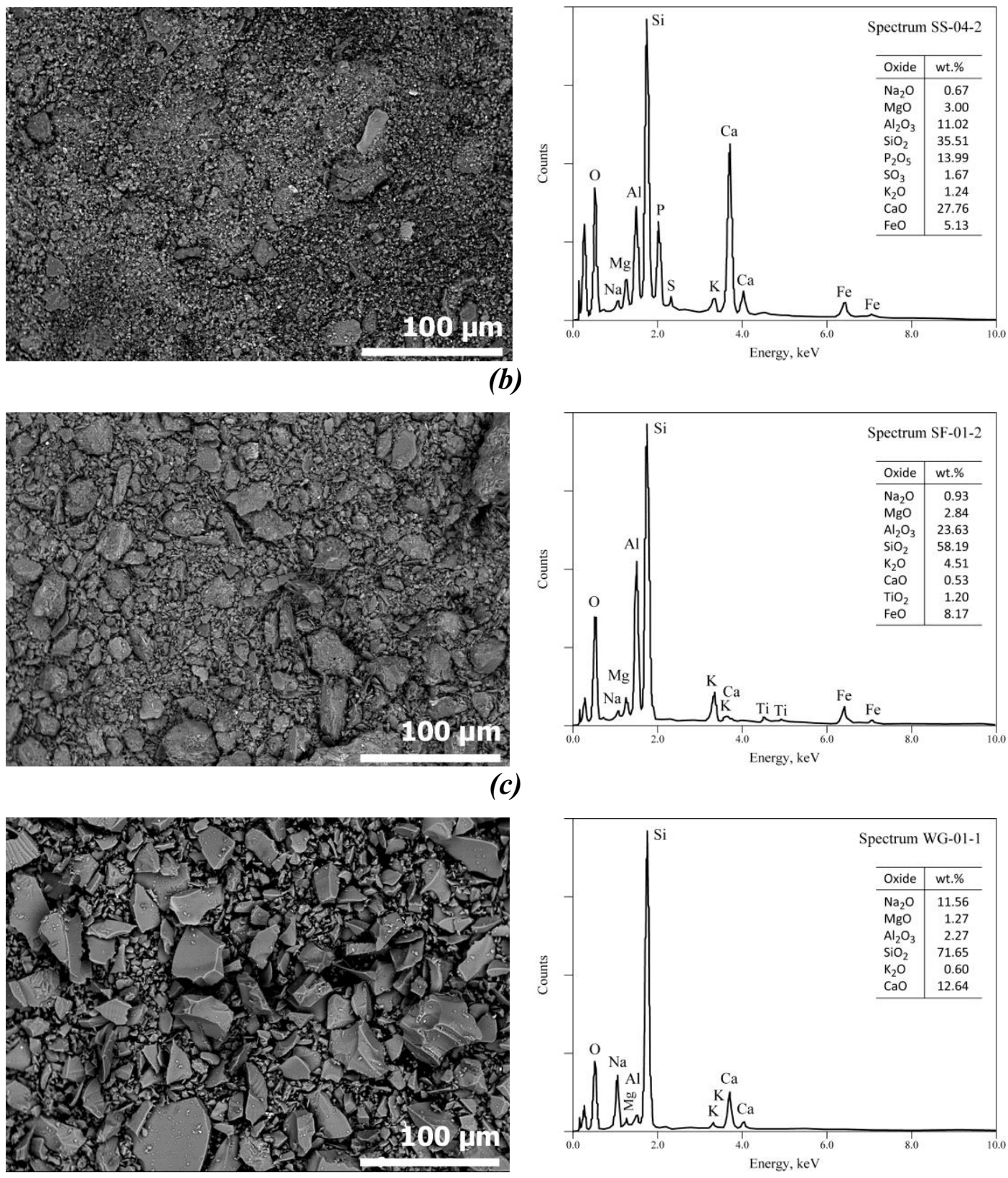

Fig. 2. Morphological aspects of the initial samples and their oxide contents for: (a) kaolinitic waste; (b) sewage sludge; (c) schist fines; (d) wasted glass. 


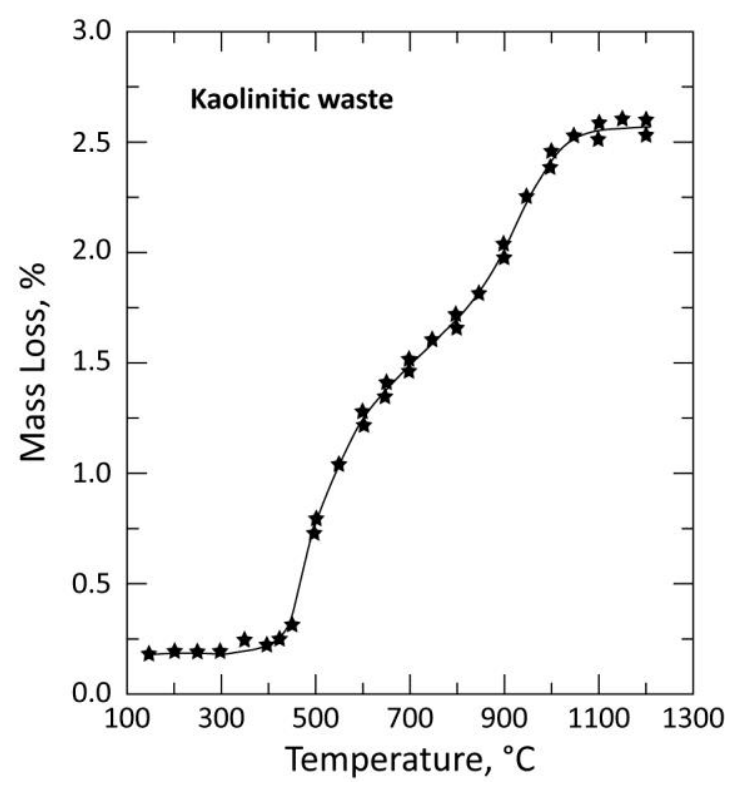

(a)

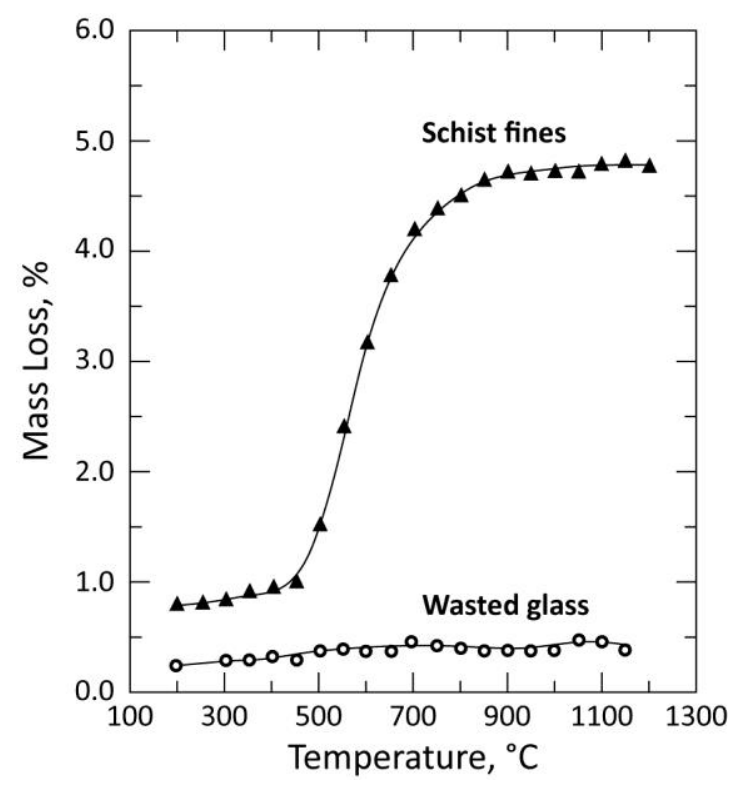

(c)

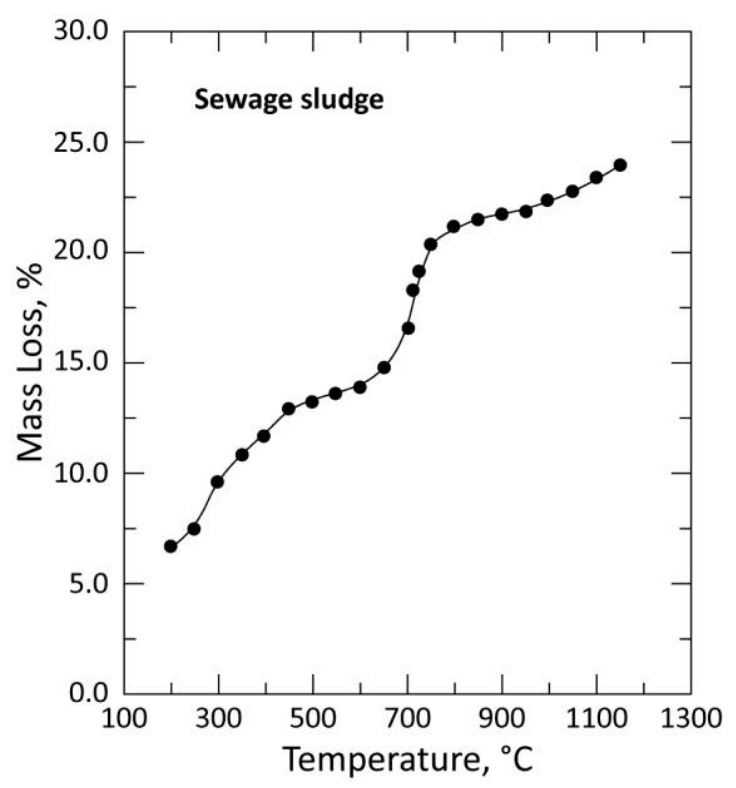

(b)
Fig. 3.

Evolution of sample mass loss as a function of temperature for: (a) kaolinitic waste; (b) sewage sludge; (c) schist fines and wasted glass during their isothermal treatment at 30 minutes. 


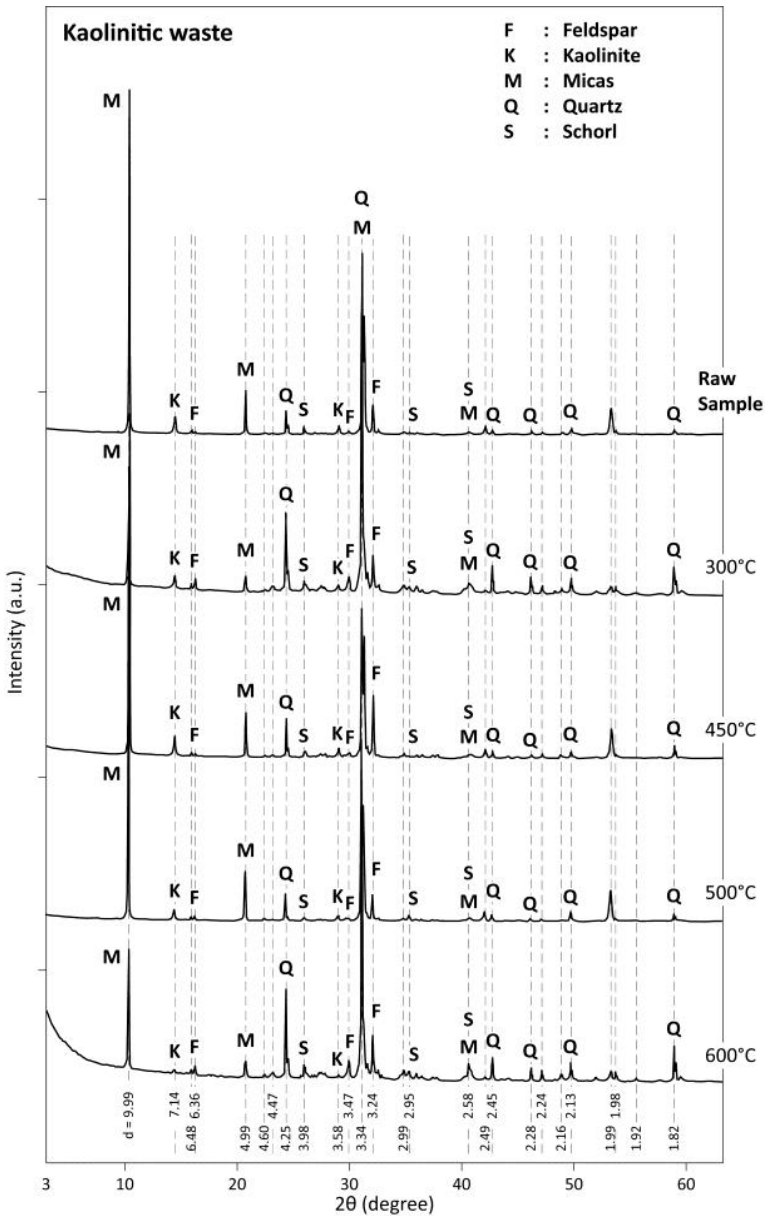

(a)

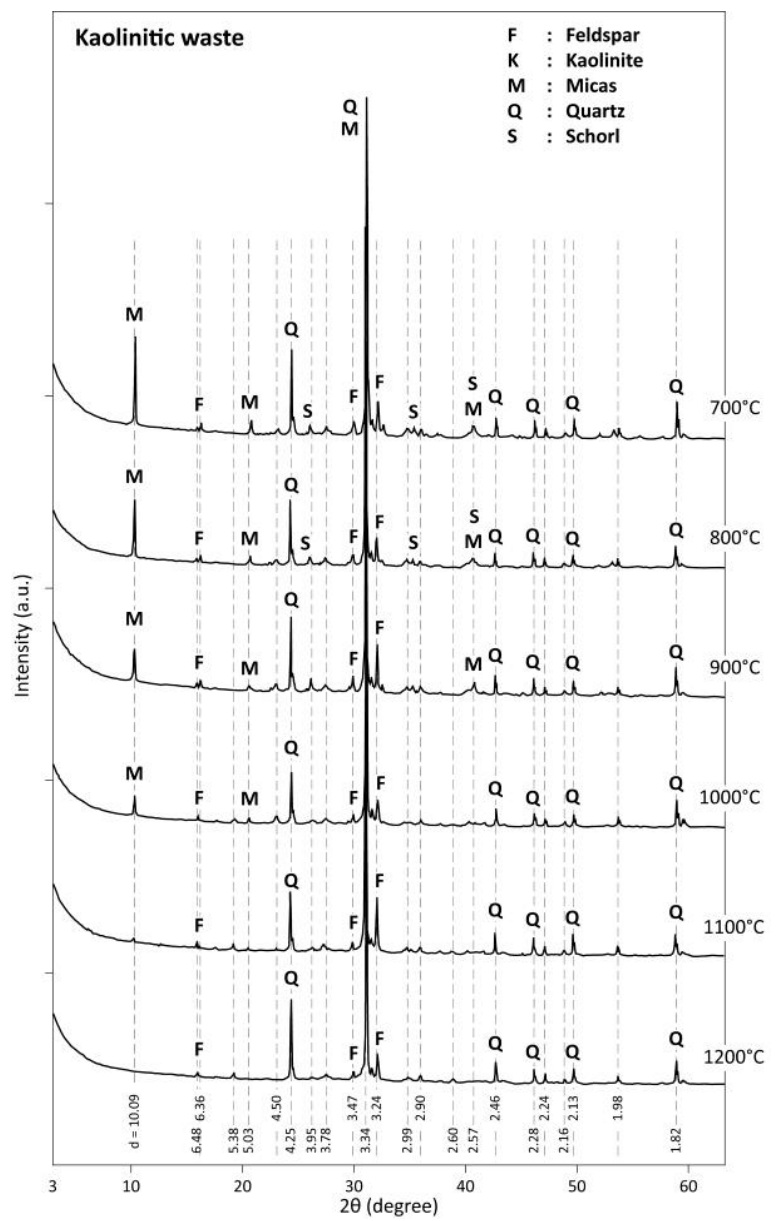

(b)

Fig. 4. XRD diagrams of the solid products issued from the thermal treatment of the kaolinitic waste sample up to $600^{\circ} \mathrm{C} \mathrm{(a)} \mathrm{and} \mathrm{from} 700^{\circ} \mathrm{C}$ to $1200^{\circ} \mathrm{C}(b)$. 


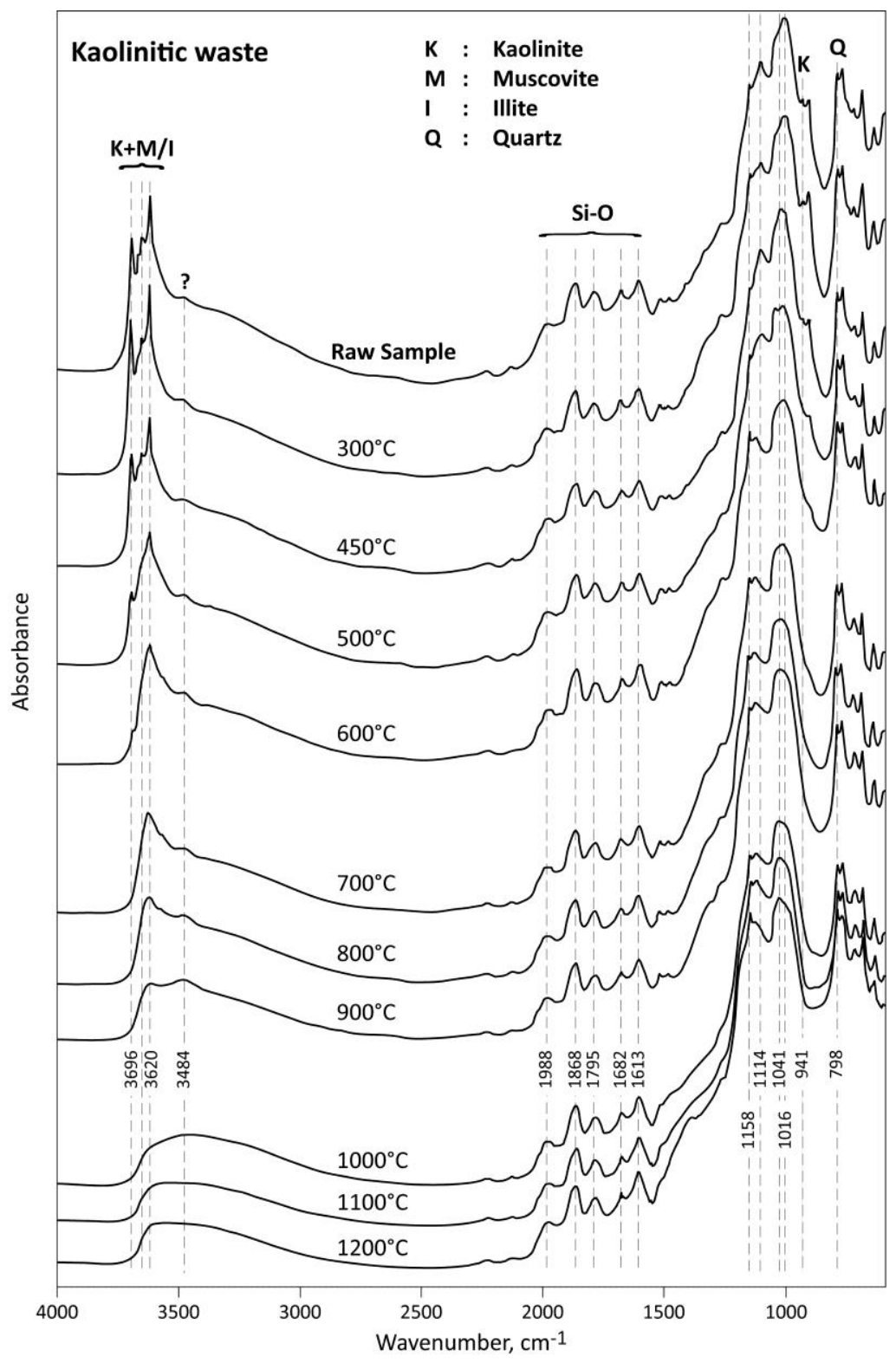

Fig. 5. IR spectra (DRIFTS) of the solid products issued from the thermal treatment of the kaolinitic waste sample at different temperatures. 


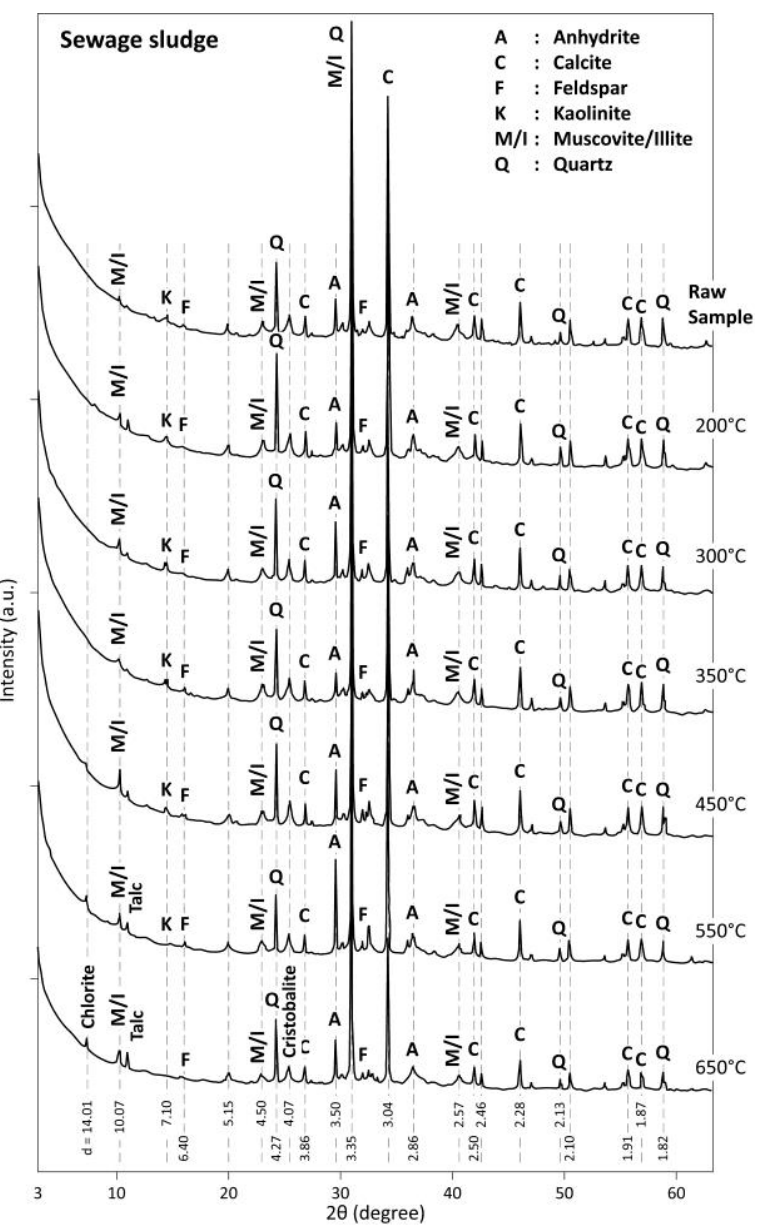

(a)

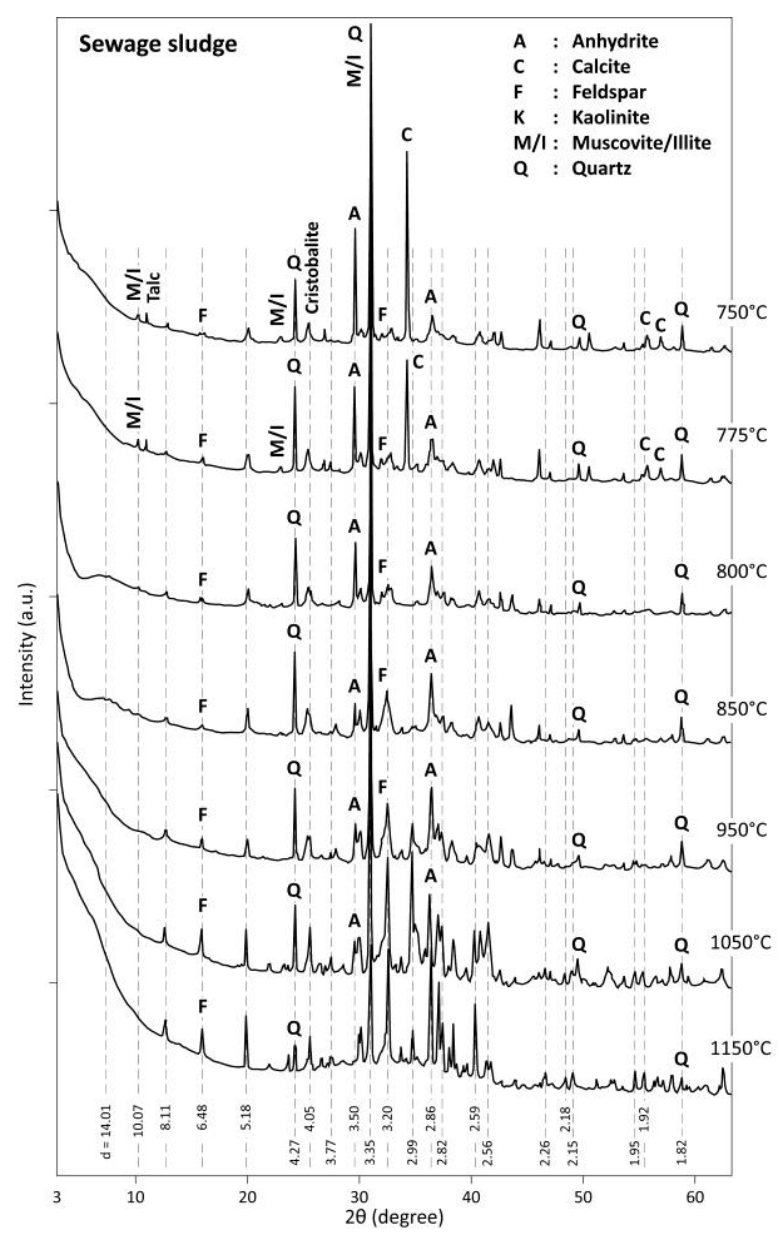

(b)

Fig. 6. XRD diagrams of the solid products issued from the thermal treatment of the sewage sludge sample up to $650^{\circ} \mathrm{C}(a)$ and from $750^{\circ} \mathrm{C}$ to $1150^{\circ} \mathrm{C}(b)$. 


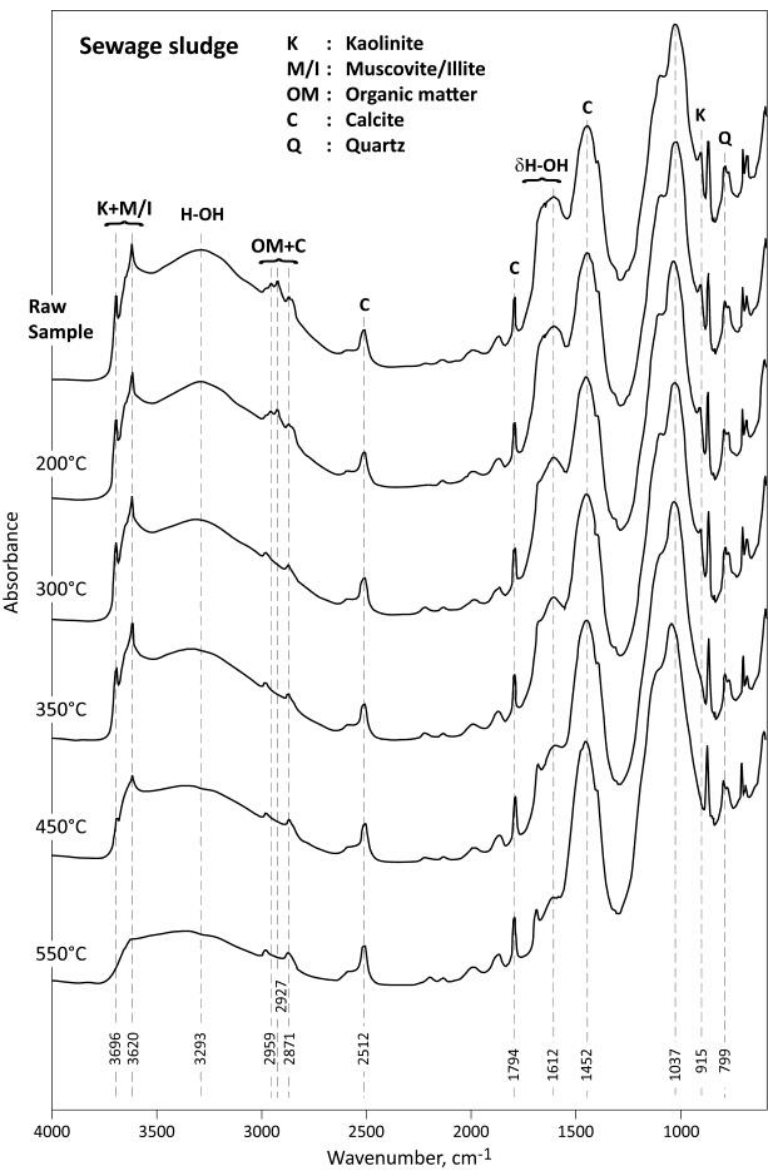

(a)

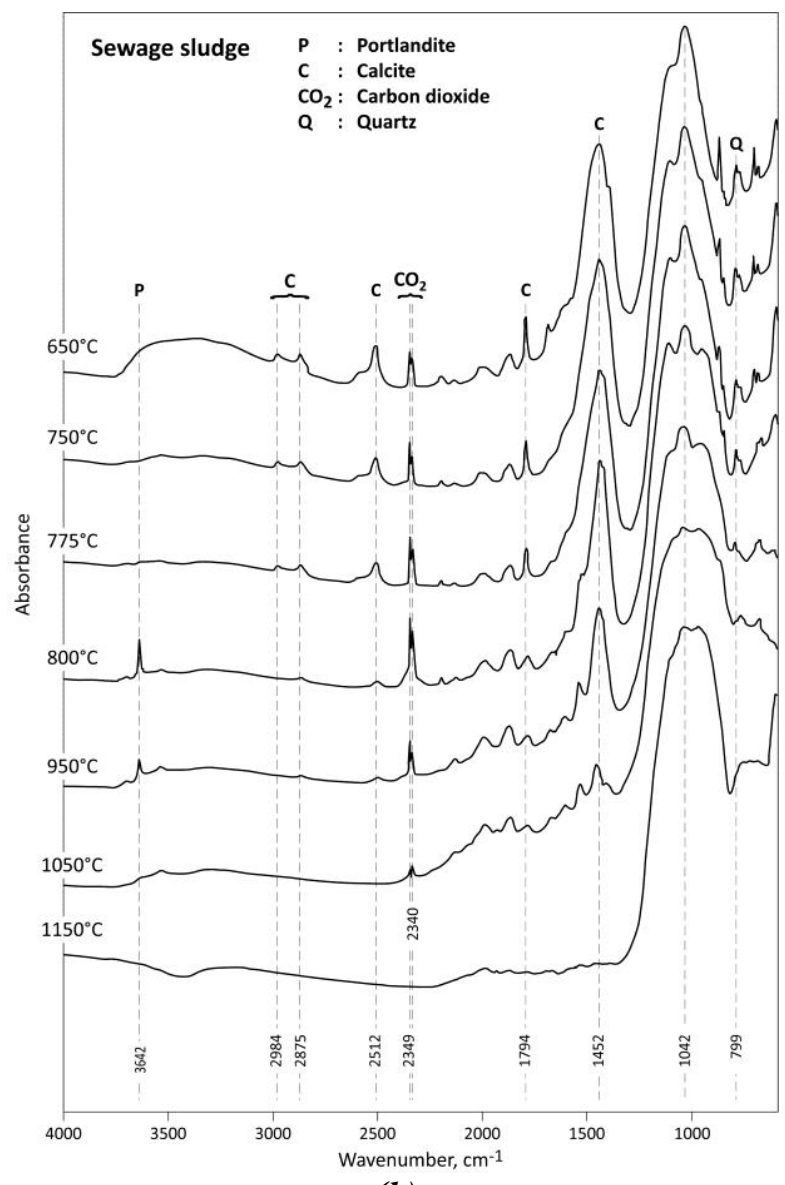

(b)
604

605

606

607

608

609

610

611

612

613

614

615

616

617

618

619

620

621

622

623

624

625

Fig. 7. IR spectra (DRIFTS) of the solid products issued from the thermal treatment of the sewage sludge sample up to $550^{\circ} \mathrm{C}(a)$ and from $650^{\circ} \mathrm{C}$ to $1150^{\circ} \mathrm{C}(b)$. 


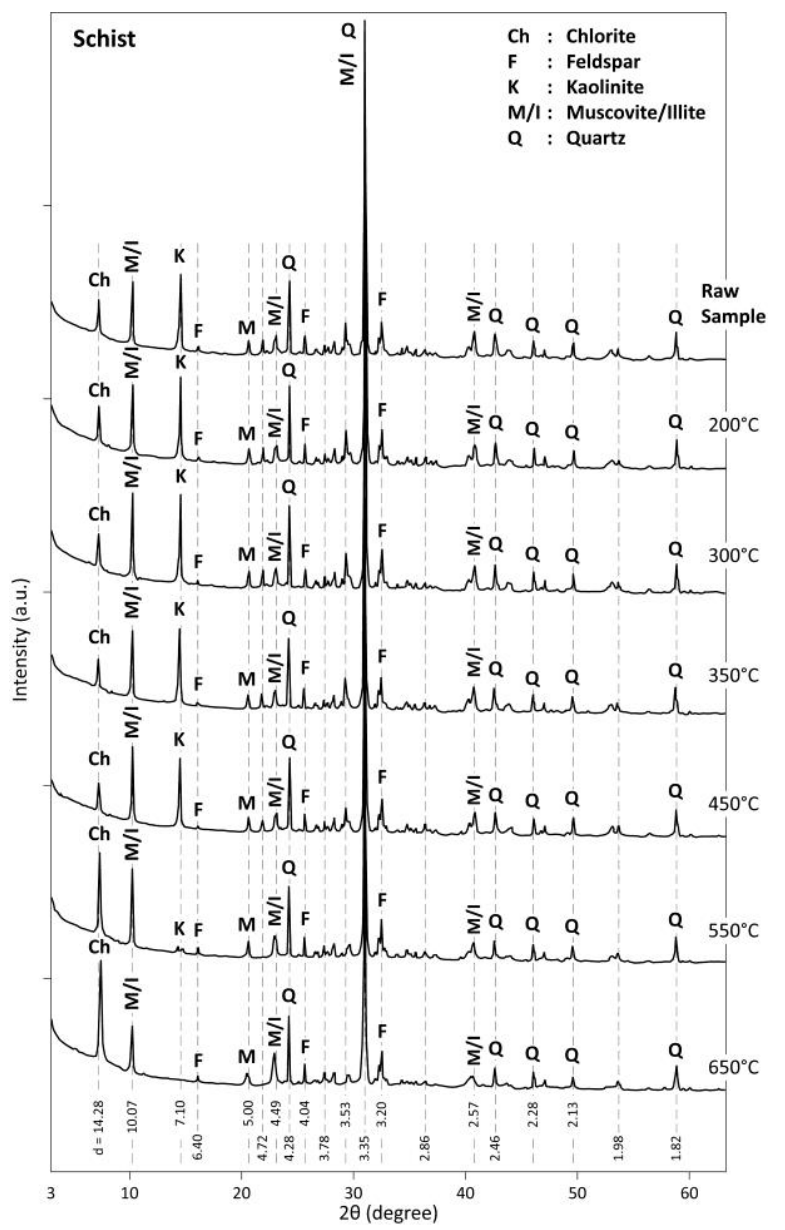

(a)

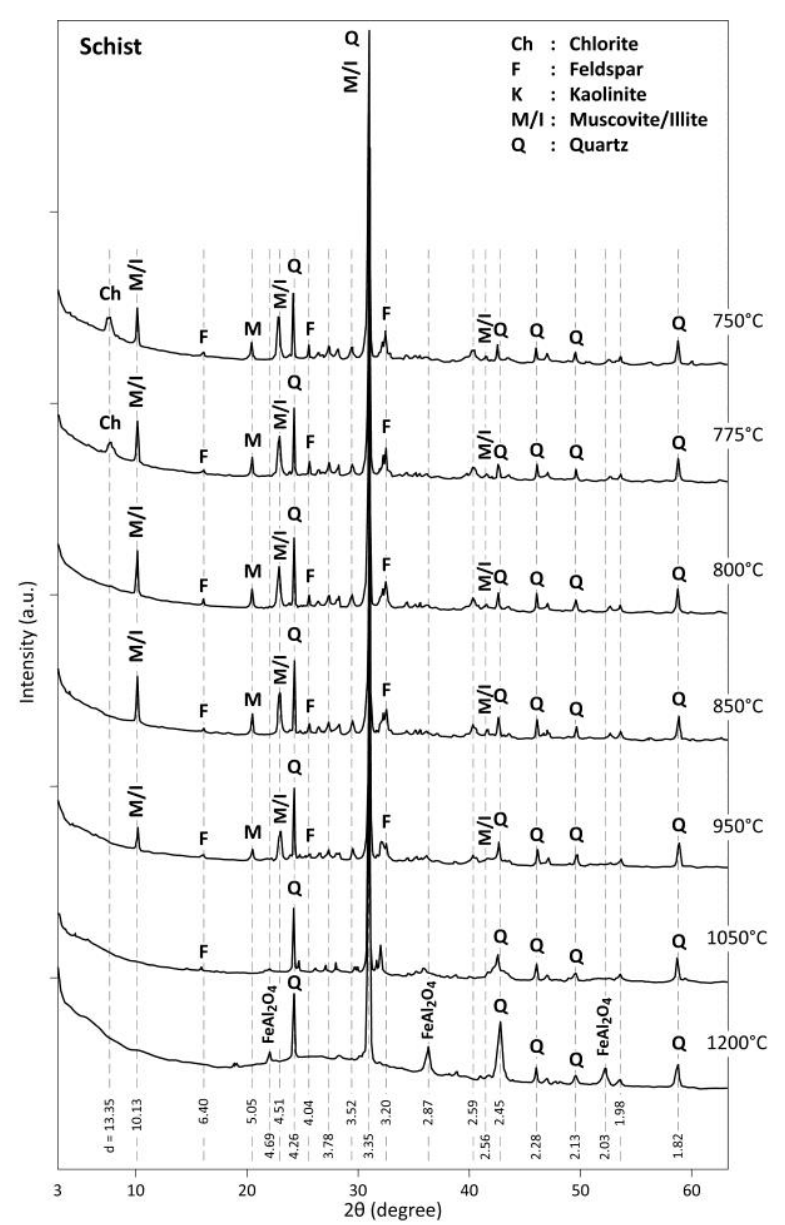

(b)

Fig. 8. XRD diffractograms of the solid products issued from the thermal treatment of the schist sample between $200^{\circ} \mathrm{C}$ and $650^{\circ} \mathrm{C}(a)$ and from $750^{\circ} \mathrm{C}$ to $1200^{\circ} \mathrm{C}(b)$. 


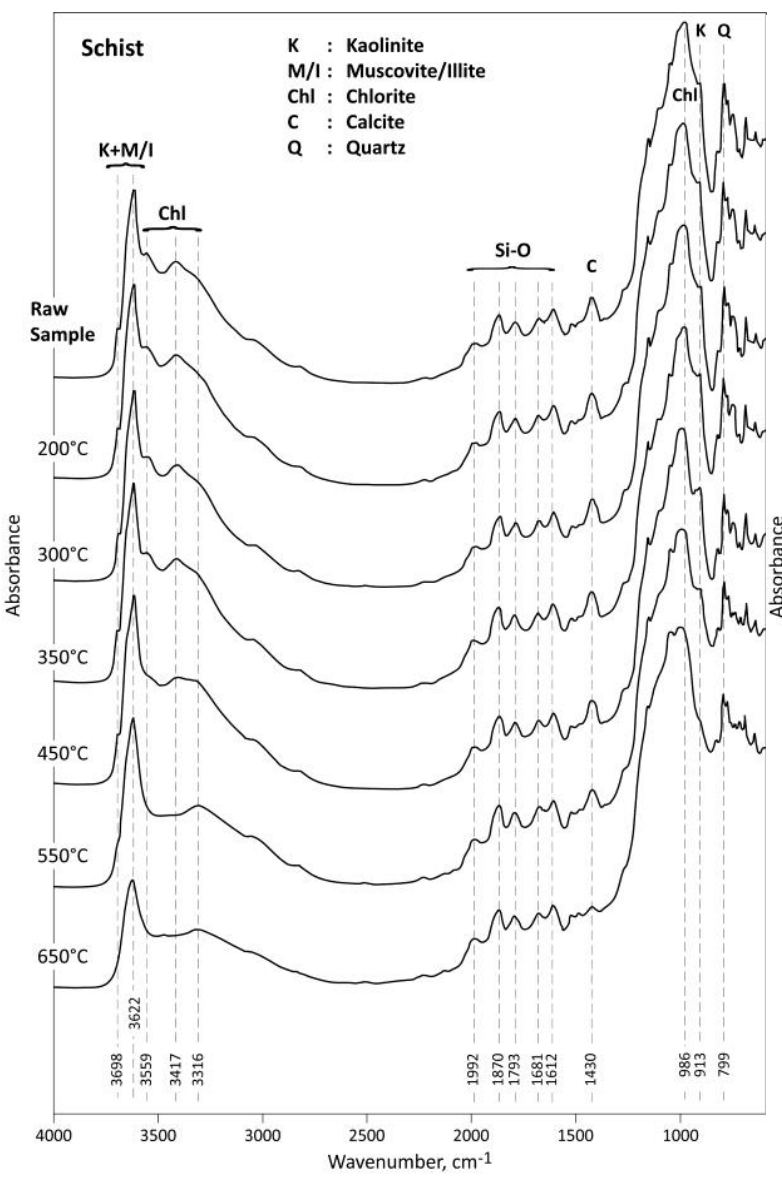

(a)

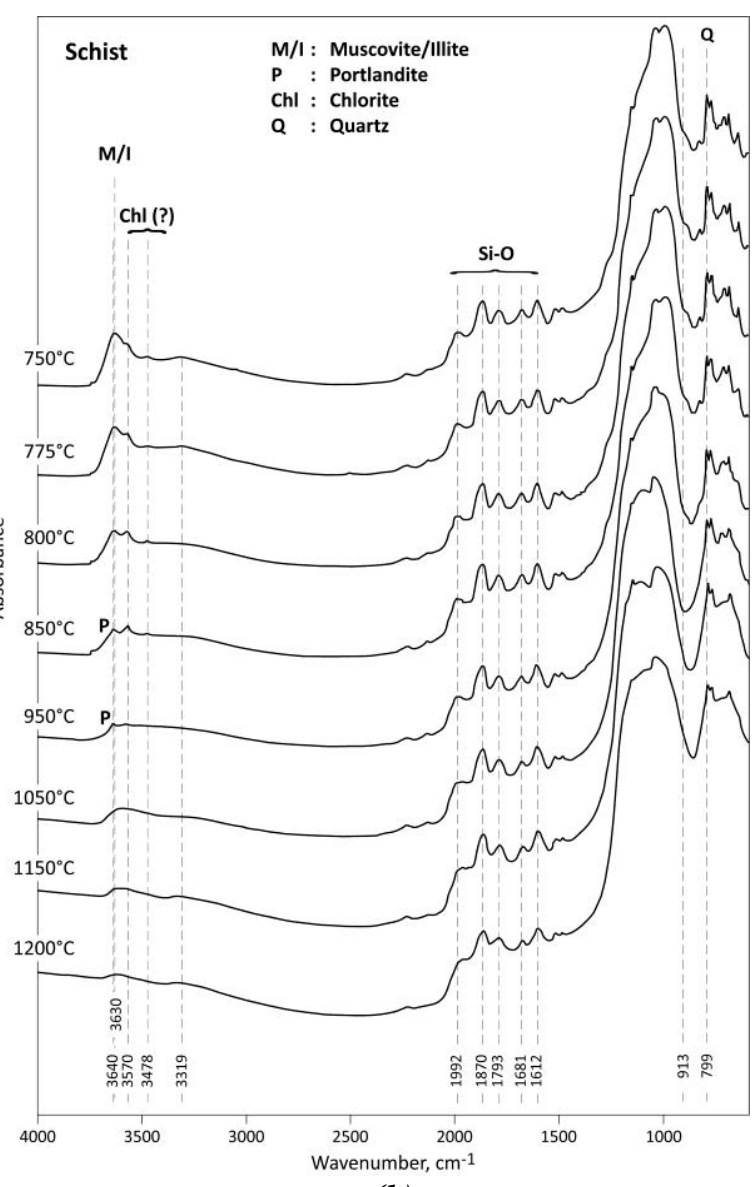

(b)

Fig. 9. IR spectra (DRIFTS) of the solid products issued from the thermal treatment of the schist sample up to $650^{\circ} \mathrm{C}(a)$ and from $750^{\circ} \mathrm{C}$ to $1200^{\circ} \mathrm{C}(b)$. 


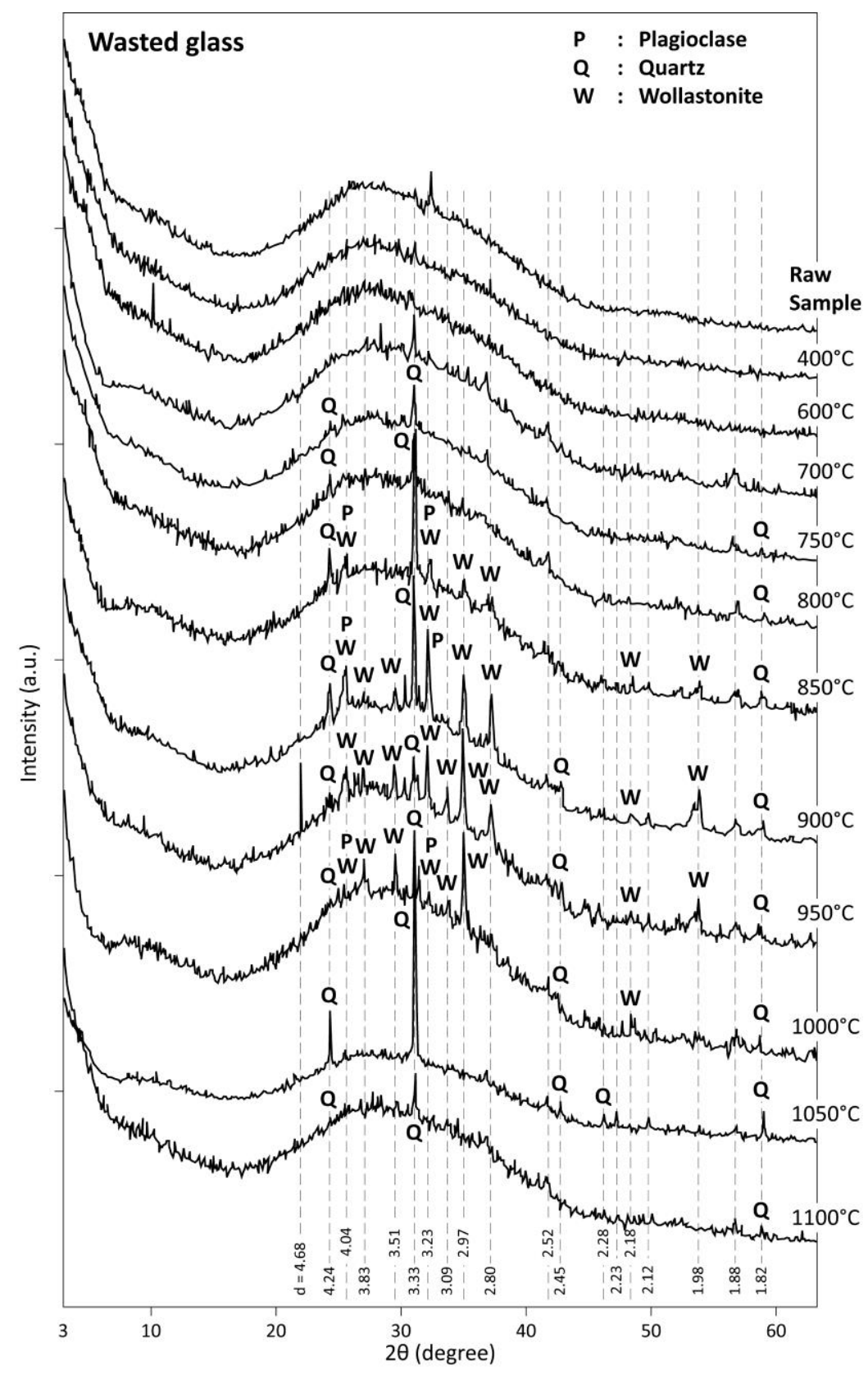

Fig. 10. XRD diffractograms of the solid products issued from the thermal treatment of the wasted glass sample between $400^{\circ} \mathrm{C}$ and $1100^{\circ} \mathrm{C}$. 
674

675

676

677

678

679

680

681

682

683

684

685

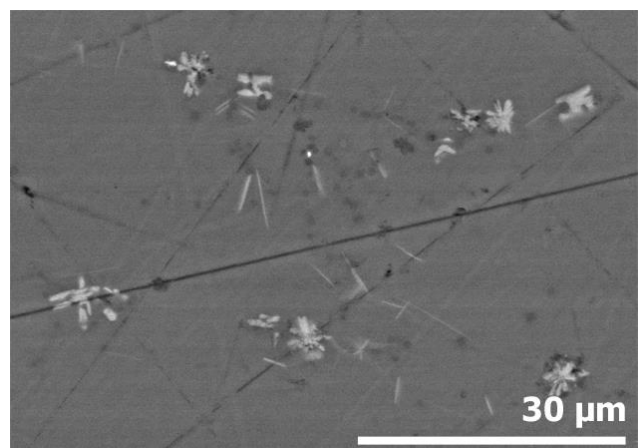

(a)

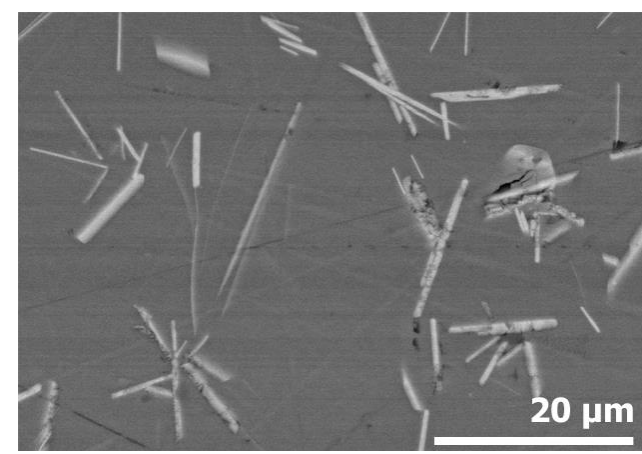

(b)

Fig. 11. Cross section of the wasted glass sample heated at $850^{\circ} \mathrm{C}(a)$ and $950^{\circ} \mathrm{C}(b)$.

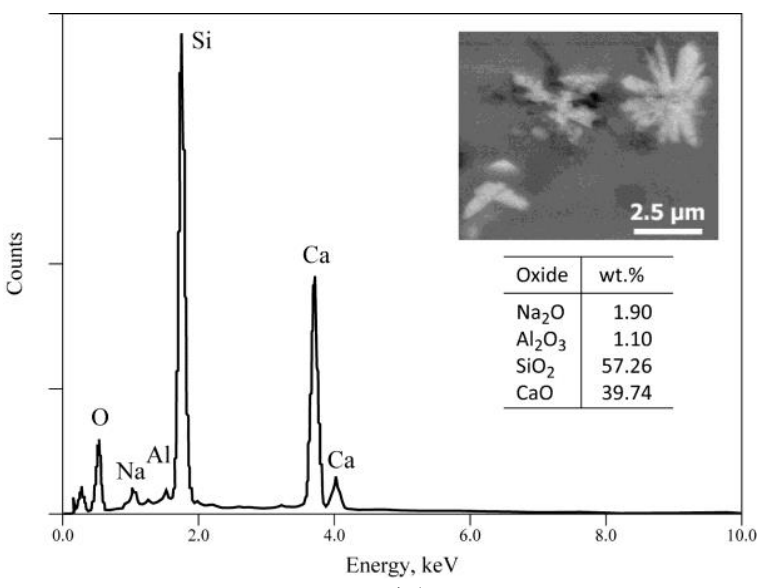

(a)

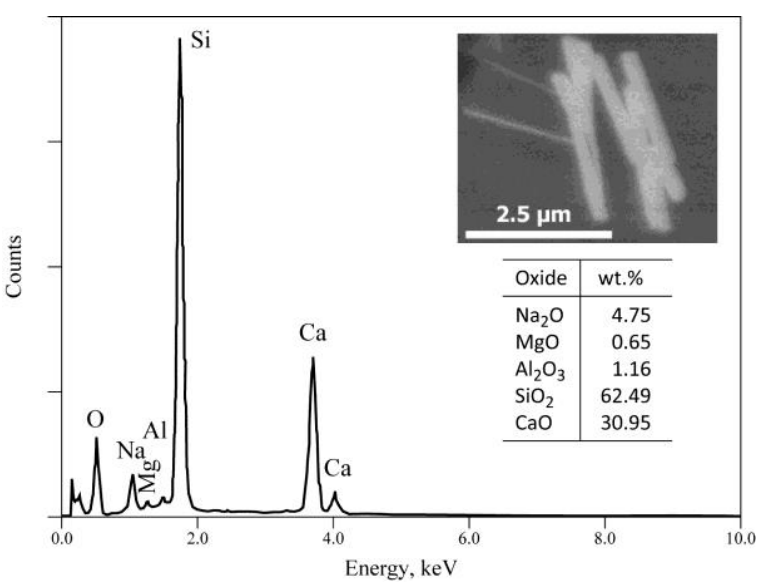

(b)

Fig. 12. SEM-EDS results of the wollastonite like crystals obtained during thermal treatment of the wasted glass sample at $850^{\circ} \mathrm{C}(a)$ and $950^{\circ} \mathrm{C}(b)$.

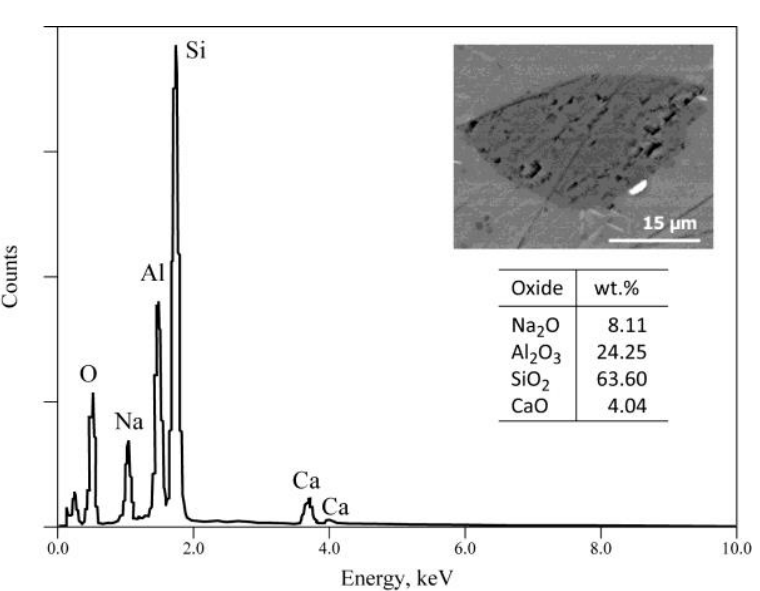

(a)

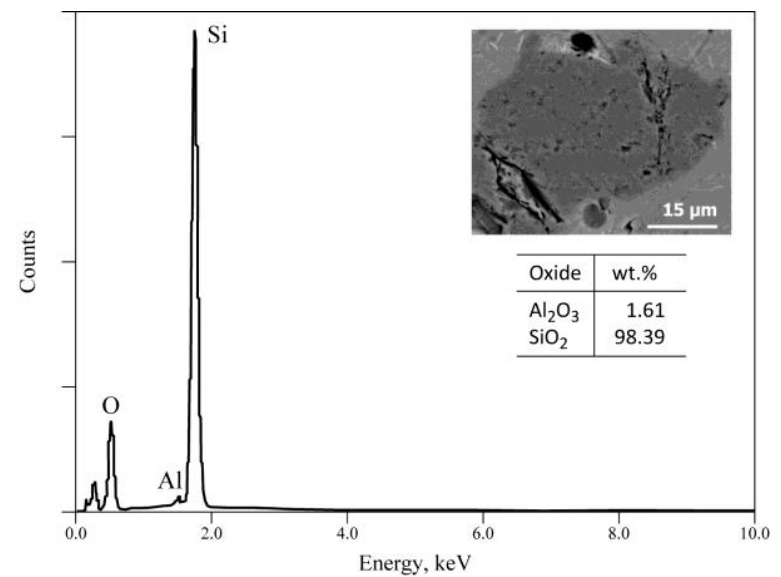

(b)

Fig. 13. SEM-EDS results of plagioclase (a) and quartz (b) particles obtained during thermal treatment of the wasted glass sample at $850^{\circ} \mathrm{C}$. 


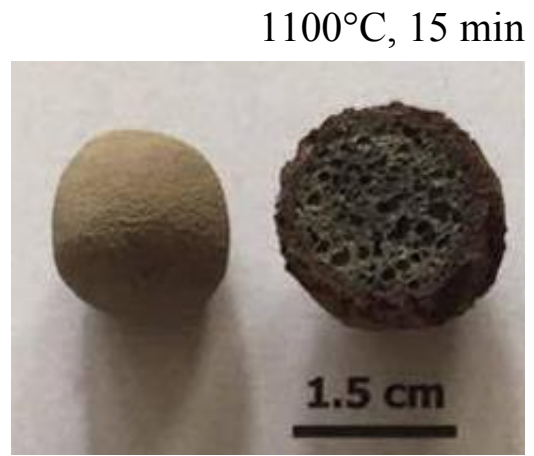

(a)

$1050^{\circ} \mathrm{C}, 10 \mathrm{~min}$

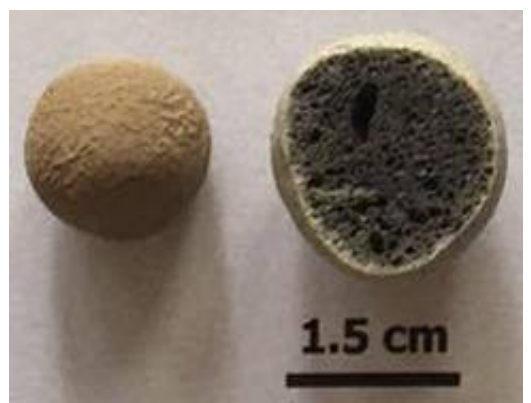

(c) $1080^{\circ} \mathrm{C}, 15 \mathrm{~min}$

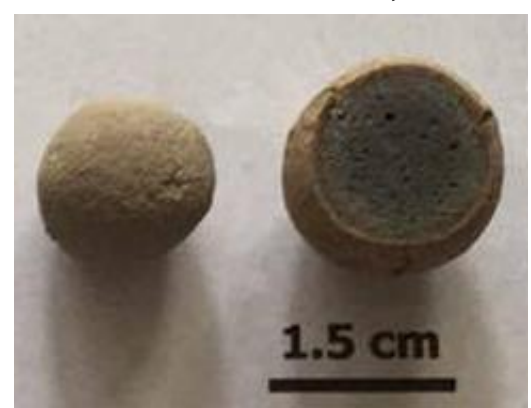

(b)

$1100^{\circ} \mathrm{C}, 10 \mathrm{~min}$

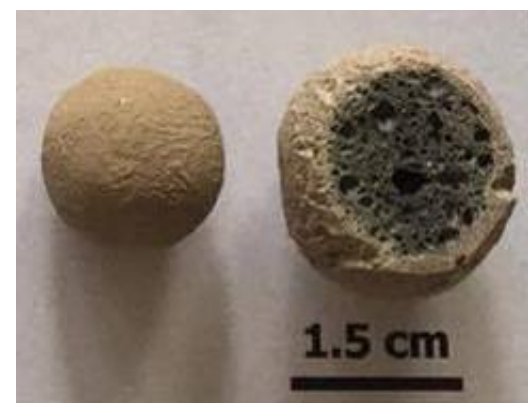

(d)
691

692 693

694

695

696

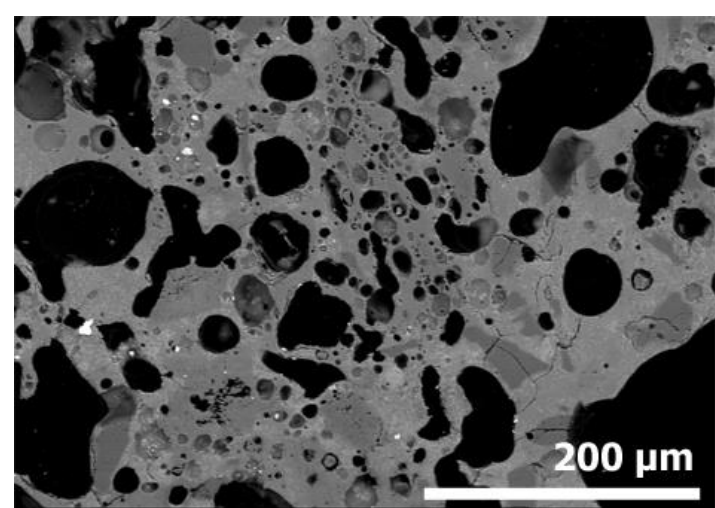

(a)

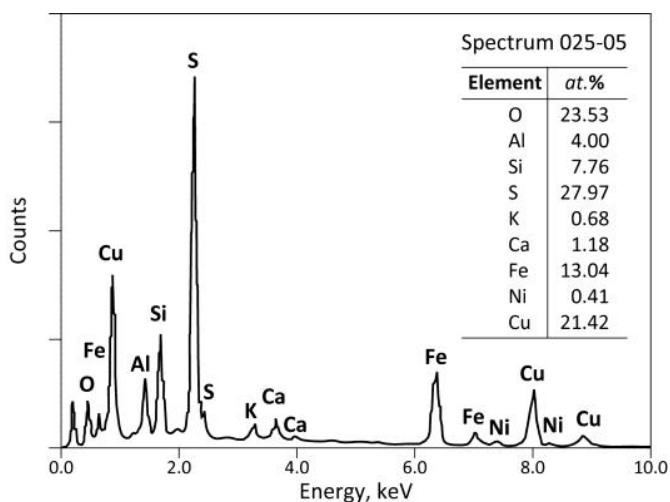

(b)

Fig. 15. SEM image of the expanded $\mathrm{M} 3$ at $1050^{\circ} \mathrm{C}(a)$ and elemental composition of bright spots $(b)$. 


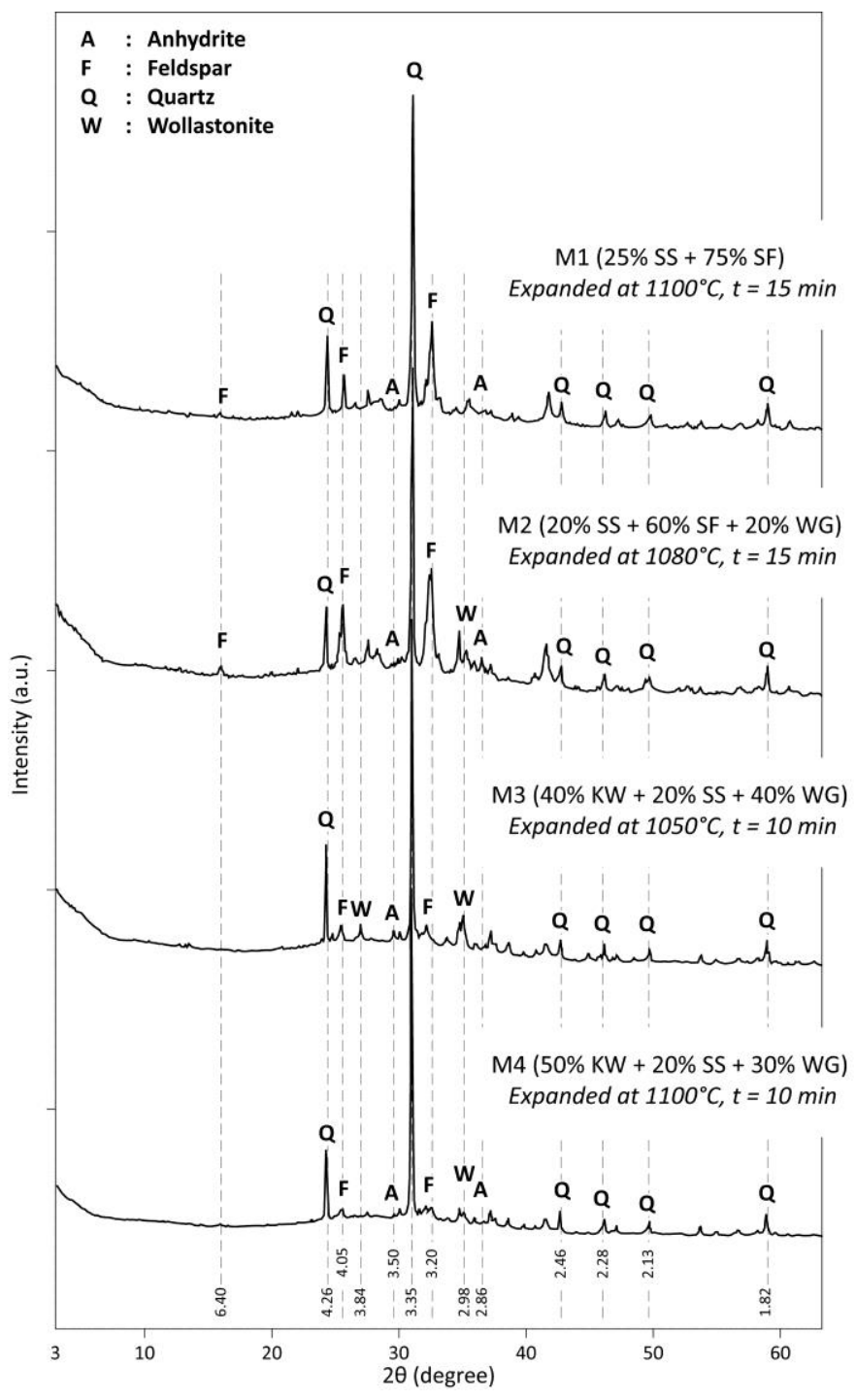




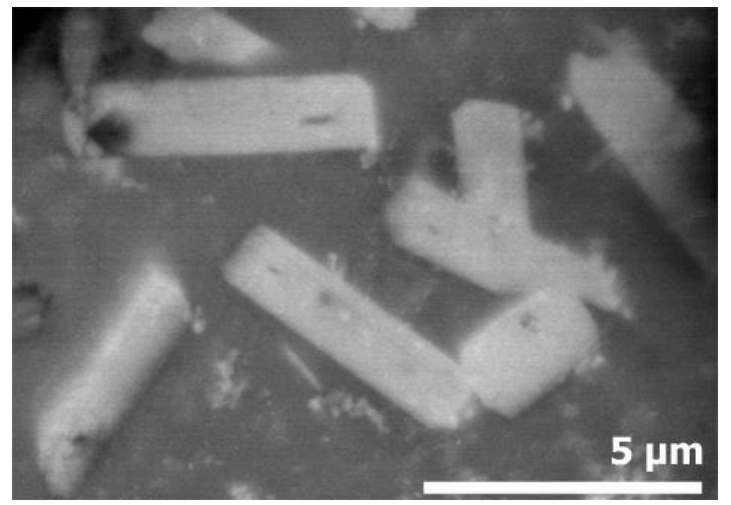

(a)

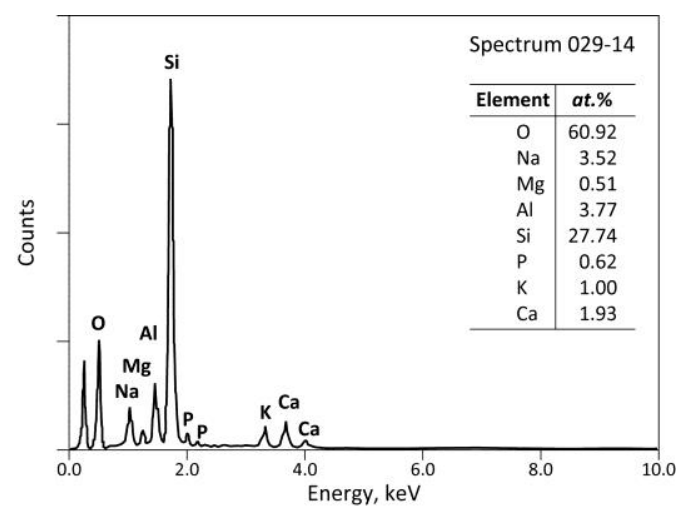

(c)

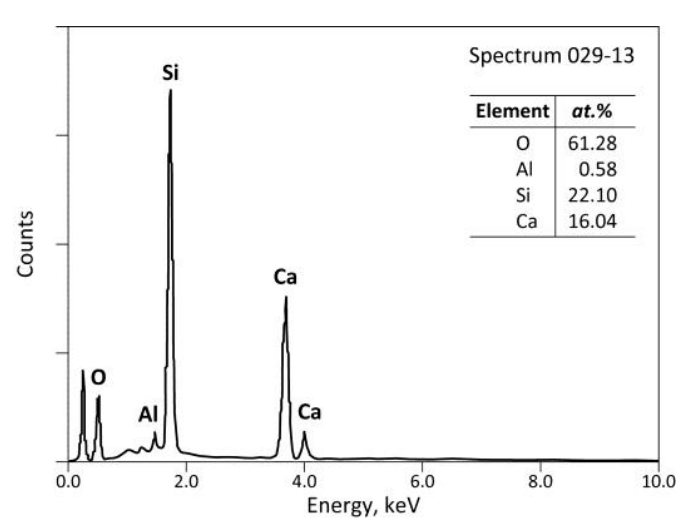

(b)
Fig. 17.

SEM-EDS results of the M3 expanded at $1050^{\circ} \mathrm{C}$ displaying: (a) morphologic aspects; (b) elemental composition of the'whiskers'; (c) elemental composition of the matrix.

741 